\title{
An experimental investigation of wage taxation and unemployment in closed and open economies
}

Citation for published version (APA):

Riedl, A. M., \& van Winden, F. (2007). An experimental investigation of wage taxation and unemployment in closed and open economies. European Economic Review, 51(4), 871-900.

https://doi.org/10.1016/j.euroecorev.2006.05.003

Document status and date:

Published: 01/01/2007

DOI:

10.1016/j.euroecorev.2006.05.003

Document Version:

Publisher's PDF, also known as Version of record

Document license:

Taverne

Please check the document version of this publication:

- A submitted manuscript is the version of the article upon submission and before peer-review. There can be important differences between the submitted version and the official published version of record.

People interested in the research are advised to contact the author for the final version of the publication, or visit the DOI to the publisher's website.

- The final author version and the galley proof are versions of the publication after peer review.

- The final published version features the final layout of the paper including the volume, issue and page numbers.

Link to publication

\footnotetext{
General rights rights.

- You may freely distribute the URL identifying the publication in the public portal. please follow below link for the End User Agreement:

www.umlib.nl/taverne-license

Take down policy

If you believe that this document breaches copyright please contact us at:

repository@maastrichtuniversity.nl

providing details and we will investigate your claim.
}

Copyright and moral rights for the publications made accessible in the public portal are retained by the authors and/or other copyright owners and it is a condition of accessing publications that users recognise and abide by the legal requirements associated with these

- Users may download and print one copy of any publication from the public portal for the purpose of private study or research.

- You may not further distribute the material or use it for any profit-making activity or commercial gain

If the publication is distributed under the terms of Article $25 \mathrm{fa}$ of the Dutch Copyright Act, indicated by the "Taverne" license above, 


\title{
An experimental investigation of wage taxation and unemployment in closed and open economies ${ }^{\hbar}$
}

\author{
Arno Riedl ${ }^{\mathrm{a}, \mathrm{b}, \mathrm{c}, *}$, Frans van Winden ${ }^{\mathrm{c}, \mathrm{d}, \mathrm{e}}$

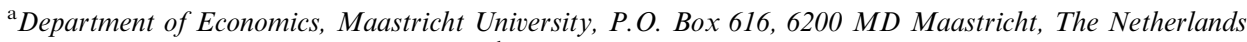 \\ ${ }^{\mathrm{b}} I Z A$, Bonn, Germany \\ ${ }^{\mathrm{c}}$ CESifo, Munich, Germany \\ ${ }^{\mathrm{d}}$ Tinbergen Institute and CREED, Faculty of Economics and Econometrics, University of Amsterdam, \\ Roetersstraat 11, 1018 WB Amsterdam, The Netherlands \\ ${ }^{\mathrm{e}} \mathrm{CEPR}$, London, $U K$
}

Received 19 May 2004; accepted 9 May 2006

Available online 22 August 2006

\begin{abstract}
We investigate experimentally the economic effects of wage taxation to finance unemployment benefits for a closed economy and an international economy. The main findings are the following. (i) There is clear evidence of a vicious circle in the dynamic interaction between the wage tax and unemployment. (ii) Employment is boosted by budget deficits but subsequent tax rate adjustments to balance the budget lead to employment levels substantially lower than theoretically predicted. (iii) A sales risk for producers due to price uncertainty on output markets appears to cause a downward pressure on factor employment. For labor the wage tax exacerbates this adverse effect. (C) 2006 Elsevier B.V. All rights reserved.
\end{abstract}

JEL classification: C90; D50; E24; F41

Keywords: Experiments; International economics; Wage taxation; Unemployment

${ }^{25}$ This paper uses data generated by a research project on the economic effects of tax systems commissioned by the Dutch Ministry of Social Affairs and Employment, see F.A.A.M. van Winden, A. Riedl, J. Wit, and F. van Dijk, "Experimenteel Onderzoek naar het Plan Van Elswijk", CREED, University of Amsterdam, 1999.

${ }^{*}$ Corresponding author. Tel.: +31433884982 .

E-mail addresses: a.riedl@algec.unimaas.nl (A. Riedl), f.a.a.m.winden@uva.nl (F.van Winden). 


\section{Introduction}

For more than two decades now unemployment has figured prominently on the political and economic agenda of many industrialized countries. Although a great number of theoretical and empirical studies exists and many proposals have been made, there is no consensus yet on how to solve the unemployment puzzle (Oswald, 1997). ${ }^{1}$

Welfare state arrangements and the accompanying tax burdens are generally considered as an important factor fostering unemployment. Using European economies as an example, Snower (2000) points out that these arrangements were established under economic fair-weather conditions. Once the weather started to deteriorate they more and more resembled quicksand. Rising unemployment led to higher social transfers, producing higher taxes on a shrinking tax base, which in turn negatively affected employment: "And so the cycle continues" (Snower, 2000, p. 44).

Indeed, quite a few studies point at a positive feedback effect of general taxes and labor taxation (the tax-wedge) on unemployment. Good examples for this group of studies are Tullio (1987) and Daveri and Tabellini (2000). The former author presents an analysis of long-run consequences of tax and public debt increases in Europe and concludes that "taxfinanced growth in government expenditure (...) has caused unemployment" (Tullio, 1987, p. 769). In a similar vein, the latter authors provide empirical evidence that in Europe high labor costs are a main cause for high unemployment rates and that these high labor costs are mainly due to high taxes on labor.

Whereas the mentioned studies clearly suggest the possibility of a vicious circle others contest its significance as a cause of unemployment. According to Oswald (1997): "Contrary to conventional wisdom, high unemployment does not appear to be primarily the result of overly generous benefits, trade union power, taxes, or wage inflexibility" (p. 14); and, more specifically: "Payroll taxes alone are uncorrelated with the pattern of unemployment across nations" (p. 8). Consistent with this view, OECD (1990, Annex 6.A) does not find any significant long-run influence of the total tax wedge on labor costs and by implication on employment. Similarly, Gruber (1997) reports that a pay-roll tax reduction of 25 percentage points, which took place in Chile in the early eighties of the last century, had only negligible effects on employment.

Thus, notwithstanding a great number of empirical investigations, ${ }^{2}$ the literature seems still undecided regarding the actual vicious nature of labor taxation. Consequently, Nickell and Layard (1999), summarize very cautiously that "the balance of the evidence suggests that there is probably some overall adverse tax effect on unemployment and labor input." (Nickell and Layard, 1999, p. 3060; emphasis added). This may not be surprising in view of the many difficulties researchers face in the field concerning the adequate specification of an econometric model dealing with the complexity of full-scale economies and the serious lack of data (see e.g. Nickell and Layard, 1999; Nickell et al., 2005).

From this perspective, it seems worthwhile to make use of a relatively novel, complementary approach: Laboratory experimentation, which is also empirical but allows

\footnotetext{
${ }^{1}$ See also Economic Policy (1997, p. 217) and Nickell et al. (2005).

${ }^{2}$ For further evidence see, e.g. Elmeskov et al. (1998), European Commission (1994), Nickell and Layard (1997), Pissarides (1998), Sørenson (1997). For a relatively early theoretical study showing the possibility of a "crowdingout-effect with massive unemployment", see van Praag and Halberstadt (1980).
} 
one to get a more focused and controlled view of specific economic mechanisms, like the nexus between labor taxation and unemployment. ${ }^{3}$ Through the investigation of relatively simple economies - which are nevertheless real in the basic sense that real people make real choices with real consequences - additional and less noisy information may be obtained about this nexus and the behavioral adjustment processes that the vicious circle argument refers to. Of course, the abstraction exploited by this research method implies a trade-off with external validity that cannot be completely avoided. ${ }^{4}$ However, note that theoretical models in fact face a similar problem. Furthermore, as we will show below, our experimental design and the results obtained capture features that are also observed in naturally occurring economies.

In our view, a particularly important contribution of laboratory experiments to macroeconomics can be that it may shed a new light on the question of the microfoundation of macroeconomics. Especially, behavioral aspects like the significance of norms or cognitive features such as loss aversion, hyperbolic discounting and bounded rationality in expectation formation can be fruitfully investigated with the help of laboratory experimentation (see e.g. Akerlof, 2002; Adam, 2005). Furthermore, it can generate interesting new empirical as well as theoretical research questions. This we also hope to show with our study.

This study is based on a research project regarding the economic performance of tax systems commissioned by the Dutch Ministry of Social Affairs and Employment, following a motion carried by the Second Chamber of the Dutch parliament. ${ }^{5}$ To the best of our knowledge, it is for the first time that policymakers explicitly asked for laboratory experiments to support macro-economic policymaking. Our paper fits into a still relatively small but growing stream of 'design' studies, as Alvin Roth labels them in his Fisher Schultz Lecture (Roth, 2002). From a broader perspective, our study is part of an emerging research field showing the usefulness of macro-economic experiments as a complementary research tool next to the more traditional methods of theoretical and field empirical analysis. $^{6}$

More specifically, we experimentally investigate the economic performance of economies operating under a wage tax financed unemployment benefit system, as it is common in many developed countries. Two different economic environments are investigated: A closed economy, and an international economy with a relatively small 'home country' and

\footnotetext{
${ }^{3}$ Natural experiments that allow for good control in outside-lab environments are rare events. An example is the case where Washington State was forced to adopt a new tax system in 1985. Anderson and Meyer (2000) use this case to investigate the tax incidence of a payroll tax.

${ }^{4}$ For a recent more general discussion of the problem of external validity of results gathered through laboratory experimentation, see Schram (2005). From the user perspective, it seems noteworthy that there is an increasing demand for policy oriented experiments (many of which concerning markets), which provides some field evidence of the perceived usefulness of this empirical research method, also for studying more complicated economic settings (see e.g. Roth, 2002; Normann and Riccuiti, 2004).

${ }^{5}$ The project was assisted by a steering committee consisting of internationally reputed scientists with expertise in public economics, labor economics, game theory, experimental economics and applied general equilibrium modeling. For more details the interested reader is referred to van Winden et al. (1999).

${ }^{6}$ On experiments concerning taxation issues, see Davis and Swenson (1993), Quirmbach et al. (1996). For other macro-economic experiments, see Bosch-Domènech and Silvestre (1997), Goeree and Holt (1999), Hey and di Cagno (1998), Lian and Plott (1998), Noussair et al. (1995, 1997, 2003), Adam (2005).
} 
a large 'foreign country'. The latter allows us to study a large and a small open economy simultaneously. In both cases there are input markets for capital and labor, and output markets for the goods produced by two production sectors. In the open economies environment, there are international markets for capital and one commodity. In each environment two tax regimes are imposed in sequence. During the first part of each experimental session the wage tax rate is held constant. This allows us to investigate whether the economies stabilize and, if so, at what level of the different economic variables. To analyze the dynamic interaction between the wage tax and unemployment as well as other indicators of economic performance, in the second part of each session, the tax rate is adjusted to the previous period's deficit in the budget of the tax-benefit system.

In this paper, we are mainly interested in investigating whether wage tax financed unemployment benefits may produce a vicious circle boosting unemployment and deteriorating the performance of an economy as a whole. We therefore abstract in this first approach from other factors conducive to unemployment, like efficiency wages or institutions fostering insider-outsider effects. Furthermore, we will not distinguish between voluntary and involuntary unemployment because, for the empirical questions at hand, this distinction is "fruitless" (Layard et al., 1991, p. 91). ${ }^{7}$ Moreover, from a budgetary point of view it does not really matter much whether in the end the benefits have to be paid for voluntarily or involuntarily unemployed units of labor.

To facilitate equilibration and efficiency we implement competitive double auctions for all markets. This trading mechanism has been shown to be very effective in fostering trade and equilibration in experimental markets (see e.g. Davis and Holt, 1993). In this way, we give the theory of competitive markets, that we will use as benchmark, its best chance to perform well. Moreover, finding a vicious circle in such a competitive environment would only strengthen the significance of the result. ${ }^{8}$

Our main findings are the following: First, for all economies we find clear evidence of a vicious circle in the dynamic interaction between the wage tax and unemployment. Second, employment seems to be boosted by deficits in the budget of the tax-benefit system. However, subsequent tax rate adjustments in order to balance the budget, as typically required by the wage tax financed unemployment benefit system, lead to employment levels that substantially fall short of the predictions obtained from the general equilibrium benchmark model. Third, and related to the previous point, there appears to be a downward pressure on the employment of production factors caused by a (disequilibrium) sales risk for producers. Due to uncertainty about output prices, and hence revenues, producers are reluctant to employ inputs. For labor this downward pressure on employment is exacerbated by the wage tax. Our results provide support for the hypothesis of a 'risk-compensated price mechanism' where the reluctance of producers to employ inputs is accompanied by (in comparison with the equilibrium predictions) too low input prices and too high output prices. This mechanism is not accounted for in general equilibrium models. Reliance on such models in policymaking would, therefore, lead to unexpected unemployment and disappointing economic performance. This may also help

\footnotetext{
${ }^{7}$ Rogerson (1997) convincingly argues that any distinction between voluntary and involuntary, frictional and cyclical, equilibrium and disequilibrium unemployment is meaningless because all unemployment consists of all these components.

${ }^{8}$ According to Snower (1994, p. 65), unemployment benefit systems typically augment common labor market failures, particularly those highlighted by efficiency wage, insider-outsider, and union theories.
} 
explain why one seems to have been taken by surprise by the vicious circle of wage taxation and unemployment.

The organization of the remainder of the paper is as follows. Section 2 presents the experimental design and theoretical predictions. Results are given and discussed in Section 3. Section 4 concludes.

\section{Experimental design and theoretical predictions}

\subsection{Experimental environment}

We consider two types of economies, a closed economy and an international economy. The latter involves two 'countries', a relatively small 'home country' $(h)$ and a relatively large 'foreign country' $(f)$. In both economies there are consumers and producers participating in computerized multiple unit double auction markets (see Plott and Gray, 1990). Each consumer $i$ is endowed with $\bar{K}_{i}$ units of capital and $\bar{L}_{i}$ units of labor that can be sold to producers $j$, as inputs on a capital and a labor market. Consumers derive utility (money earnings in the experiment) from 'leisure', the unsold units of labor $\bar{L}_{i}-L_{i}$, and the consumption of two commodities, $X_{i}$ and $Y_{i}$. In addition to their proceeds from sales, they obtain an unemployment benefit for each unsold unit of labor that can be used for the purchase of consumption goods on the output markets. Goods $X$ and $Y$ are produced in two separate sectors. The producers in these sectors need capital and labor as inputs, which are transformed to outputs via given production technologies. The technologies for the two goods differ in the sense that the production of good $X$ is relatively capital-intensive whereas the production of good $Y$ is relatively labor-intensive. Producers derive experimental earnings from profits, determined by the difference between their proceeds from sales in their respective output market and the costs of inputs. The cost of labor includes a proportional wage tax.

In total, there are four markets in the closed economy: Two factor markets (for $K$ and $L$ ) and two output markets (for $X$ and $Y$ ). In the international economy, both the capital market and the market for $X$ are 'international' ('exposed'), whereas the markets for labor and commodity $Y$ are 'local' ('sheltered'). Consequently, the total number of markets in this economy equals six. To implement a large foreign economy in the lab-making the home country similar to a 'small' open economy-we choose the following design.

While keeping the number of consumers and producers the same for both countries in the international economy, we endow the consumers in the foreign country with seven times as many units of labor and capital as the consumers in the home country. Moreover, a scaling factor in the production functions of foreign producers is adjusted such that theoretically supply and demand in the foreign economy are seven times as high as in the home economy. Table 1 shows the parameters of the experimental economies, including continuous approximations of the earnings functions (utility and profit functions) of consumers and producers, and the production technology of producers. ${ }^{9}$

\footnotetext{
${ }^{9}$ In addition to the endowment of capital and labor for consumers both consumers and producers are endowed with some cash to facilitate trading. Note, also, that with the requirement of at least three agents on each side of a market (as e.g. in Quirmbach et al., 1996), which seems to be the smallest number of agents ensuring that the markets approximate competitiveness (see also Davis and Holt, 1993, p. 150), the minimal number of subjects would have been 64 , in case of the alternative approach of increasing numbers of agents instead of endowments. Apart from potential control problems with that many subjects, lab size restrictions urged us to choose the design of this study.
} 
Table 1

Experimental parameters ${ }^{\mathrm{a}}$

Preferences (in each period $t$ ):

$\begin{array}{ll}\text { Consumers: } & U_{i t}=25\left[\ln X_{i t}+\ln Y_{i t}+0.25 \ln \left(\bar{L}_{i}-L_{i t}\right)\right] \\ & U_{i t}=0 \text { if either } X_{i t}, Y_{i t} \text {, or } \bar{L}-L_{i t} \text { equals zero } \\ \text { Producers: } & \Pi_{j t}=p_{z t} Z_{j t}-\left(1+\tau_{t}\right) w_{t} L_{j t}-r_{t} K_{j t}, Z=X, Y\end{array}$

In international economy: $p_{y t}, Y_{j t}, \tau_{t}, w_{t}$, and $L_{j t}$ are determined 'locally' (within a country)

$p_{x t}, X_{j t}, r_{t}, K_{j t}$ are determined 'internationally'

(one international market)

Parameters (in each period $t$ ):

Endowments (per economic agent) and francs/Dutch cents conversion rates

Closed economy International economy

\begin{tabular}{|c|c|c|c|}
\hline & & & \\
\hline & & Home country & Foreign country \\
\hline Consumers & $\begin{array}{l}\bar{L}_{i}=60, \bar{K}_{i}=40 \\
\text { Cash }_{i}=725\end{array}$ & $\begin{array}{l}\bar{L}_{i}=15, \bar{K}_{i}=10 \\
\operatorname{Cash}_{i}=181\end{array}$ & $\begin{array}{l}\bar{L}_{i}=105, \bar{K}_{i}=70 \\
\text { Cash }_{i}=1268\end{array}$ \\
\hline & ${\text { Conversion } \text { rate }_{i}=1.2}$ & Conversion rate $e_{i}=3.6$ & 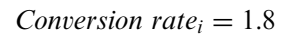 \\
\hline$X$ producers & $\bar{L}_{j}=0, \bar{K}_{j}=0$ & $\bar{L}_{j}=0, \bar{K}=0$ & $\bar{L}_{j}=0, \bar{K}_{j}=0$ \\
\hline & $\mathrm{Cash}_{j}=4890$ & Cash $_{j}=1223$ & $\operatorname{Cash}_{j}=8557$ \\
\hline & 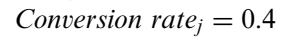 & Conversion rate $_{j}=2.8$ & 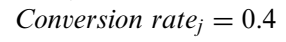 \\
\hline$Y$ producers & $\bar{L}_{j}=0, \bar{K}_{j}=0$ & $\bar{L}_{j}=0, \bar{K}_{j}=0$ & $\bar{L}_{j}=0, \bar{K}_{j}=0$ \\
\hline & $\mathrm{Cash}_{j}=3260$ & $\operatorname{Cash}_{j}=815$ & $\mathrm{Cash}_{j}=5705$ \\
\hline & 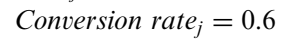 & Conversion rate $e_{j}=4.2$ & 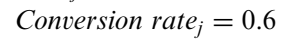 \\
\hline
\end{tabular}

Number of

agents:

$\begin{array}{llll}\text { Consumers } & 6 & 3 & 3 \\ X \text { producers } & 4 & 2 & 2 \\ Y \text { producers } & 6 & 3 & 3\end{array}$

Production (in each period $t$ ):

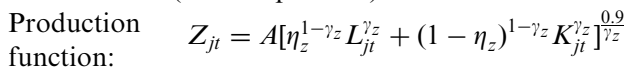

Labor intensity: $\eta_{x}=0.5625, \eta_{y}=0.6750$

Substitution elasticity: $\gamma_{x}=-2, \gamma_{y}=-6$

Scaling factor $A$ : 1.15 in closed economy

1 for home country in international economy

1.21 for foreign country in international

economy

'Government' (in each period $t$ ):

Unemployment

benefit: $\quad w_{0}=70$

Wage tax $\tau_{t}=.3777$ in 'constant tax periods'

rate:

$\tau_{t+1}=\frac{w_{0}}{w_{t}} \frac{\bar{L}-L_{t}}{L_{t}}$ in 'variable tax periods' $\left(\bar{L}=\sum_{i} \bar{L}_{i}, L_{t}=\sum_{j} L_{j t}\right)$

with an upper bound of $0.9^{*}$

\footnotetext{
${ }^{\mathrm{a}}$ In the table subscript $i(j)$ is used for consumers (producers); missing time subscripts $t$ indicate that the variable or parameter is constant over time. ${ }^{*}$ This upper limit was set given the experience with another tax system investigated in van Winden et al. (1999). Pilot studies showed that tax rates too close or even above $100 \%$ might have a strong discouraging effect on trading.
} 
Consumer preferences are induced by a log-linearized version of a Cobb-Douglas-type utility function. We used a Cobb-Douglas-type because it guarantees an interior optimum and - together with other assumptions - the existence of a general equilibrium. The use of a log-linearized version has the advantage that it can be presented to the experimental subjects in a simple way showing only the marginal and total payoff for each of the three arguments, leisure and consumption goods $X$ and $Y$. An example of such a table can be found in Appendix B.1.

Producers production schedules are discrete approximations of the CES production functions shown in the lower part of Table 1. The functions exhibit slightly decreasing returns to scale allowing producers to make strictly positive profits in the theoretical equilibrium. Furthermore, the implemented factor intensities and elasticities of substitution differ in the two sectors and resemble estimates for the Dutch economy. To the subjects production schedules are presented in the form of tables. An example of such a table can be found in Appendix B.2.

Fig. 1(a) presents a flow diagram of all goods for the more complex international economy. A flow diagram of the closed economy can be generated by deleting all symbols and arrows referring to the foreign country, for instance. Rectangles represent economic agents (consumers and producers) while oval forms represent markets where these agents can buy and sell factors and commodities. The arrows depict the flow of these goods. For instance, 'consumers in home country' (upper left rectangle) can sell their labor endowments on the local 'labor market in home country' and their capital endowments on the 'international capital market' on which also 'consumers in foreign country' (lower left rectangle) are active. On the 'international capital market' and the local labor markets producers can buy the respective factors from consumers active on these markets. The flow of commodities from producers to consumers via the markets for $Y$ and $X$ works in an equivalent way.

We took care to make the closed economy similar to the international economy. In particular, the closed economy should also be 'large'. In the closed economy, the total number of consumers and producers is the same as in the international economy. Consumers are endowed with four times as many units of capital and labor as consumers in the home country of the international economy. The scaling factor in the production function of producers is adjusted such that theoretically supply and demand will be four times as large as in the home country of the international economy.

In both economies 'francs' are used as the experimental currency unit, implying that only one currency exists in the open economies. ${ }^{10}$ The rates at which earnings in francs were converted into Dutch guilders (conversion rate) can be found in Table 1. This table (bottom) also shows the two ways in which the wage tax is implemented. During the first seven (closed economy) or eight (international economy) trading periods into which the experimental sessions are divided (see below) the tax rate is kept constant, while it adjusts to the previous period's budget deficit (that is, outlays on unemployment benefits minus

\footnotetext{
${ }^{10}$ Since we are not focusing on issues of international finance, we do not want to complicate the experiments by introducing multiple currencies. Generally, the use of an artificial experimental currency is common practice in experimental market economies (see, e.g. Noussair et al., 1995; Quirmbach et al., 1996). In our experiment the use of such a currency has the advantage that it allows us to equalize the expected earnings of subjects in different roles, based on the theoretical model.
} 
(a)

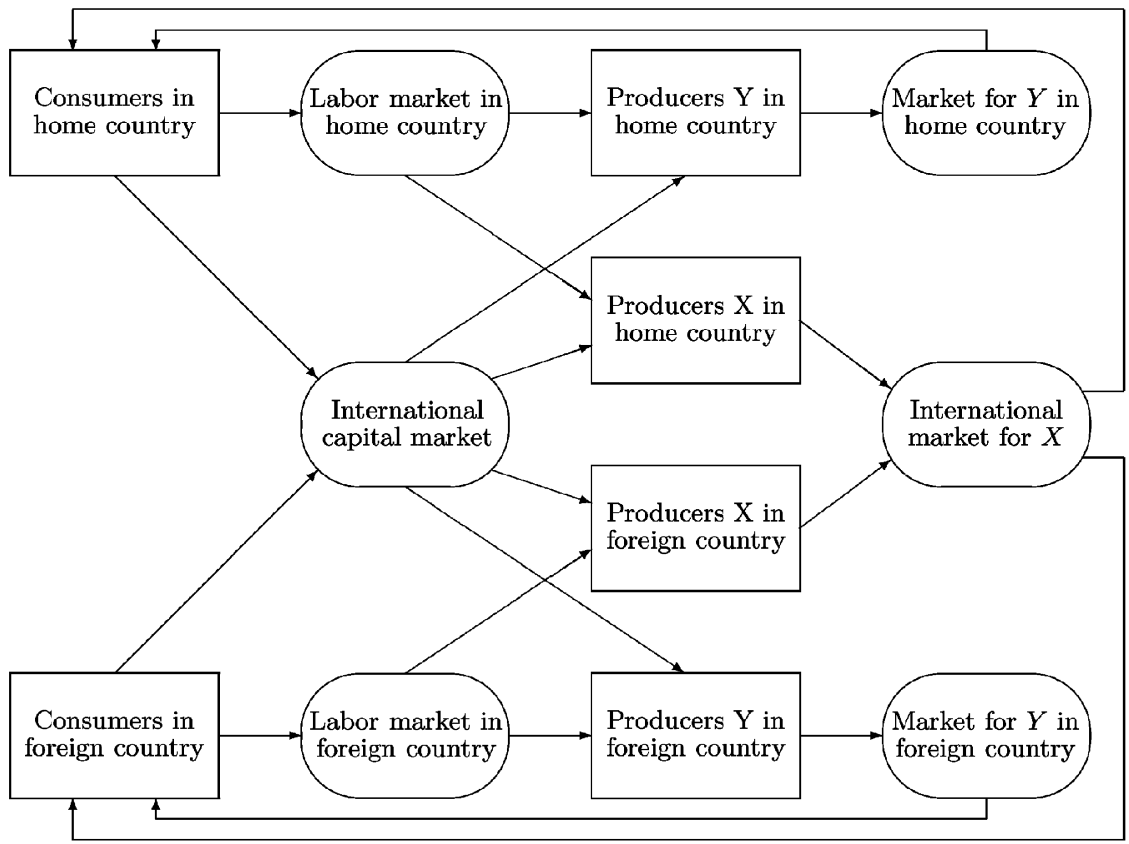

Panel (a) above depicts a diagram of the flows of factors and commodities in the more complex international economy. A description is given in the main text.

\begin{tabular}{|c|c|c|c|} 
Input markets open & Production & Output markets open & Calculation of gains \\
\hline Phase 1 & Recording time & Phase 2 & Recording time
\end{tabular}

Panel (b) above depicts the sequence of events in a trading period. The markets for inputs are open in 'Phase 1' in which consumers (producers) can sell (buy) labor and capital. This is followed by a short break in which subjects can record their sales and production of goods $X$ and $Y$ is determined. Thereafter, in 'Phase 2', the markets for outputs are open in which producers (consumers) can sell (buy) the produced commodities. At the end of a trading day the proceeds from sales are calculated and subjects have time to record their earnings and evaluate

(b) their decisions.

Fig. 1. Flow diagram of the international economy (a) and sequence of events (b).

tax revenues) in the later periods. The reason for choosing this procedure is twofold. Firstly, we need a sufficient number of repetitions in a constant environment with exactly the same conditions in each period to see if economic behavior stabilizes and at what level. ${ }^{11}$ Secondly, we want to analyze the dynamic interaction between the wage tax and indicators of economic performance, if the wage tax adjusts to deficits (surpluses), while

\footnotetext{
${ }^{11}$ In less complex experimental competitive environments behavior usually stabilizes - in the neighborhood of the theoretical predictions - within the first few periods (Davis and Holt, 1993).
} 
Table 2

Summary of experimental sessions

\begin{tabular}{llllll}
\hline Date & Economy & $\begin{array}{l}\text { Number of } \\
\text { subjects }\end{array}$ & Experience & $\begin{array}{l}\text { Number of } \\
\text { periods }^{\mathrm{a}}\end{array}$ & $\begin{array}{l}\text { Number of } \\
\text { constant tax periods }\end{array}$ \\
\hline $05 / 10 / 98$ & Closed & 16 & Training & $14(3)$ & 7 \\
$05 / 10 / 98$ & Closed & 16 & Training & $13(3)$ & 7 \\
$06 / 10 / 98$ & Closed & 16 & Training & $12(3)$ & 7 \\
$06 / 10 / 98$ & Closed & 16 & Training & $14(3)$ & 7 \\
$08 / 10 / 98$ & International & 16 & Closed economy & $16(2)$ & 8 \\
$08 / 10 / 98$ & International & 16 & Closed economy & $16(2)$ & 8 \\
$09 / 10 / 98$ & International & 16 & Closed economy & $16(2)$ & 8 \\
\hline
\end{tabular}

${ }^{\mathrm{a}}$ Number of practice periods in parentheses.

keeping the other conditions constant. Note, however, that we do not impose an intertemporal budget constraint forcing it to balance the budget across all periods. Our main goal is to examine how the markets react to the introduction of some fiscal discipline, while keeping all other parameters the same.

\subsection{Procedures}

In total seven experimental sessions were conducted: Four concerning the closed economy, and three involving the international economy. Table 2 provides some data characterizing these sessions. All experiments were run at the CREED-laboratory of the University of Amsterdam. Subjects, undergraduates at the University and mostly coming from its Faculty of Economics and Econometrics, participated in three meetings. At the first meeting they got thoroughly acquainted with the trading rules, forms, tables, and the software of the double auction markets. Producers and consumers were separately trained. ${ }^{12}$ Then, at the second meeting, subjects participated, in their respective role, in the closed economy experiment. Again after a few days, this was followed by the third meeting concerning the international economy experiment. Each meeting lasted about $3.5 \mathrm{~h}$. Because of the complexity of the international economy (with one of the novel aspects being the many units to be traded by subjects in the foreign economy), it was decided to use only experienced subjects for this experimental environment. The closed economy experiment, with its intermediately sized endowments, enabled subjects to gain experience with a similar (but not identical) environment. ${ }^{13}$

\footnotetext{
${ }^{12}$ To avoid experimenter-induced effects, the bids and asks of the experimenters who acted as counterparts in the markets for training were randomly varied within a considerable range, which was the same for all training sessions.

${ }^{13}$ Furthermore, subjects were selected for the international economy experiment on the basis of their performance (earnings) in the closed economy experiment. All subjects got informed about this during the first meeting. Subjects received a show-up fee of 70 guilders (31.80 euro) for the training. They got a show-up fee of 40 guilders (18.20 euro) and earned on average 27 guilders (12.25 euro) in the closed economy session. For the international economy session these figures were, respectively, 10 and 67 guilders (4.55 and 30.45 euro). All money was paid out privately at the end of the third meeting.
} 
At the beginning of the experiments subjects received the instructions, consisting of a general part which was read aloud and a specific part to be read by themselves. The specific part only presented instructions that were relevant to the subject in its specific role of consumer or producer. Apart from similar information provided on the computer screen, subjects received personal history forms containing all the information that was relevant to the subject (endowments, markets they were allowed to trade in, any taxes or subsidies, and the conversion rate of francs into guilders). ${ }^{14}$ By having them fill in their purchases, sales, and earnings these forms were also intended to make subjects fully aware of the consequences of their actions. Quizzes were used to check the understanding of the procedures, the reading of the redemption values and production schedules, and the calculation of earnings. ${ }^{15}$

Each experiment consisted of a number of trading periods, with a couple of practice periods at the beginning in which no money was earned. Except for the adjustment of the wage tax in later periods, all periods were identical in terms of endowments and parameter values. Apart from subjects' earnings, nothing carried over from one period to the next. Each period was divided into two phases. In the first phase the factor markets for capital and labor were open, while in the second phase the product markets were open. Including some recording time and time to look up information, each phase took about 5 min. Fig. 1(b) depicts the sequence of events.

Standing bids and asks in the labor market were presented as 'market prices' (exclusive of the wage tax) and as 'inclusive prices' (including the tax), where for consumers the former and for producers the latter was highlighted on the computer screen. After the closing of the factor markets consumers were informed about the unemployment benefits received due to unsold labor units, while producers were informed about the number of goods produced with the inputs they bought. In addition, some market statistics were provided concerning the amounts of capital and labor traded, average prices, and the average price subjects received (paid) for the inputs they sold (bought). After the closing of the product markets similar market statistics were provided on the computer screen.

\subsection{Theoretical predictions}

The theoretical benchmark is based on a general equilibrium model. In our view, such a model describes our experimental economies, exhibiting several interdependent markets and the highly competitive double auction trading mechanism, in a most suitable way. The excess demand functions are derived under the assumption of utility and profit maximizing behavior using the functional forms and parameter values shown in Table 1.

In the investigated economies a general equilibrium requires that the excess demands on all markets are zero and additionally, that wage tax rates are set such that the budget of the tax-benefit system is balanced. The complexity of the economies makes it impossible to find analytical solutions. We, therefore, calculated the general equilibrium numerically. Similar benchmark modeling is used in other studies of complex experimental markets (e.g. Noussair et al., 1995, 1997, 2003; Quirmbach et al., 1996).

\footnotetext{
${ }^{14}$ In the experiment consumers were labeled 'type-I traders' and producers 'type-II traders'. Labor and capital were denoted as good V and good W, respectively. Markets were labeled as V1(2), W1, X1, and Y1(2); the unemployment benefit was denoted as a subsidy for unsold units of $\mathrm{V}$.

${ }^{15} \mathrm{~A}$ sample copy of all material used in the experiments is available upon request from the authors.
} 
Table 3

Theoretical predictions

\begin{tabular}{|c|c|c|c|c|}
\hline \multirow[t]{2}{*}{ Variable } & \multirow[t]{2}{*}{ Closed economy } & \multicolumn{3}{|c|}{ International economy } \\
\hline & & Home country & & Foreign country \\
\hline \multicolumn{5}{|l|}{ Production: } \\
\hline$X$ & 177 & 22 & 177 & 155 \\
\hline$Y$ & 151 & 19 & & 132 \\
\hline \multicolumn{5}{|l|}{ Factor employment: } \\
\hline$K$ & 240 & 30 & 240 & 210 \\
\hline$L$ & 226 & 28 & & 197 \\
\hline Unemployment rate $^{\mathrm{a}}$ & $37 \%$ & $37 \%$ & & $37 \%$ \\
\hline \multicolumn{5}{|l|}{ Relative prices: $^{\mathrm{b}}$} \\
\hline$p_{x}$ & 0.3088 & & 0.1882 & \\
\hline$p_{y}$ & 0.3628 & 0.2211 & & 0.2211 \\
\hline$r$ & 0.0504 & & 0.0307 & \\
\hline$w$ & 0.2780 & 0.1694 & & 0.1694 \\
\hline \multicolumn{5}{|l|}{ 'Government': } \\
\hline Budget balance & 0 & 0 & & 0 \\
\hline Wage tax rate & 0.3777 & 0.3777 & & 0.3777 \\
\hline
\end{tabular}

${ }^{a}$ For convenience, the unemployment rate is calculated with respect to total initial endowment of labor units, i.e. the potential labor force.

${ }^{\mathrm{b}}$ Relative prices are defined by dividing nominal prices with the sum of all nominal prices. The relative prices in the international economy differ from those in the closed economy, since there are two local markets for labor and the labor intensive product $Y$, respectively. Treating each of them as just one market would give the same relative prices in the closed economy and the international economy.

Table 3 shows the general equilibrium levels of factor employment, commodity production (which equals consumption in equilibrium), relative prices, and the 'government' variables wage tax and budget balance. The second column shows the predictions for the closed economy and the third and fifth column depicts the results for the home and foreign country, respectively, in the international economy. The fourth column shows overall equilibrium quantities of good $X$ and factor $K$ that are traded internationally and the relative prices of these goods on the international markets. Due to our parameter choices, the overall equilibrium quantities, the unemployment rate, and the equilibrium wage tax in the international economy match those in the closed economy. Furthermore, the home and the foreign country in the international economy are perfectly symmetric except for their size. These equilibrium features facilitate a comparison of actual behavior across economies.

\section{Empirical analysis}

In this section we present our main experimental results and observations. We first concentrate on the functioning of the economies in a more general way and their performance relative to the theoretical benchmark predictions under the constant tax regime. Then, we will zoom in on the issue whether indeed a vicious circle in the dynamic 
interaction between wage taxation and unemployment can be observed. In this context we will also look at the impact of budget deficits on employment. Finally, we present and provide evidence for a behavioral explanation of the observed divergence between the empirical results and the theoretical predictions.

\subsection{General performance of the economies}

The first result concerns the functioning of the experimental economies.

Result 1. The development of prices in both the closed and the international economy shows a clear structure, with generally most variation during the initial periods. Furthermore, both the ratio of employed inputs and the ratio of outputs are inversely related to the respective price ratio, in line with the theoretical prediction.

Support: Focusing first on the initial periods with a constant tax rate we find that the average standard deviation of transaction prices in the first two periods is larger than in the last two periods of the constant tax regime. This holds for the closed as well as the international economy and for all markets, except one. In the later periods, when the tax rate adjusts to the previous period budget deficit this property cannot be confirmed for all markets. We attribute this to the changing tax rates in this tax regime, which induce larger price variations and thus uncertainty into the economies (see Observation 4). Regarding the input markets generally a (mostly significant) positive relationship between the capital-labor employment ratio and the inverse input price ratio is observed. A similar picture concerning the relationship between the $\mathrm{X}-\mathrm{Y}$ consumption ratio and the inverse of the output price ratio is obtained for the output markets. ${ }^{16}$

Figs. 2 and 3 illustrate the development of the quantities and prices over the periods. The straight horizontal lines indicate the theoretical predictions. Fig. 2 shows the evolution of sales of inputs and outputs (averaged across sessions). Perhaps the most striking result is the decrease in economic activity once the tax rates start to adjust to the previous period budget deficit or surplus, which happens in period 8 in the closed economy and in period 9 in the international economy. We will come back to this below. Here we will mainly focus on the constant tax periods. Notice, that with only one exception (labor employment $L_{\mathrm{h}}$ in the home country of the international economy) all quantities start too low in comparison

\footnotetext{
${ }^{16} \mathrm{We}$ tested these relationships by using cross-sectional time series FGLS regressions (allowing for heteroscedasticity between panels and $\mathrm{AR}(1)$ within panels; we also allowed for different intercepts per session by using session dummies.). The units of observation for the input market regressions are the ratio of employed capital and employed labor (as dependent variable) and the ratio of the average nominal inclusive wage and the average nominal capital price (as independent variable), per session and period. For the output market regressions, the dependent variable is the ratio of $\mathrm{X}$-consumption and $\mathrm{Y}$-consumption, and the independent variable the ratio of the average nominal price of $\mathrm{Y}$ and the average nominal price of $\mathrm{X}$. With respect to the input markets the coefficient of the price ratio shows the 'right' positive sign for all sectors, except the Y-sector in the home country where it is insignificantly negative. For the X-sectors in the closed economy and the foreign country in the international economy, as well as sector $\mathrm{Y}$ in the foreign country the coefficient is significantly positive at least at the 5\% level. For the X-sector in the home country and the Y-sector in the closed economy the coefficient of the price ratio is positive but not significant. With respect to the output markets we find, for both countries in the international economy, the expected positive coefficient for the price ratio, which is significant at the $10 \%$ level in both cases. For the closed economy the coefficient is negative but not significant.
} 

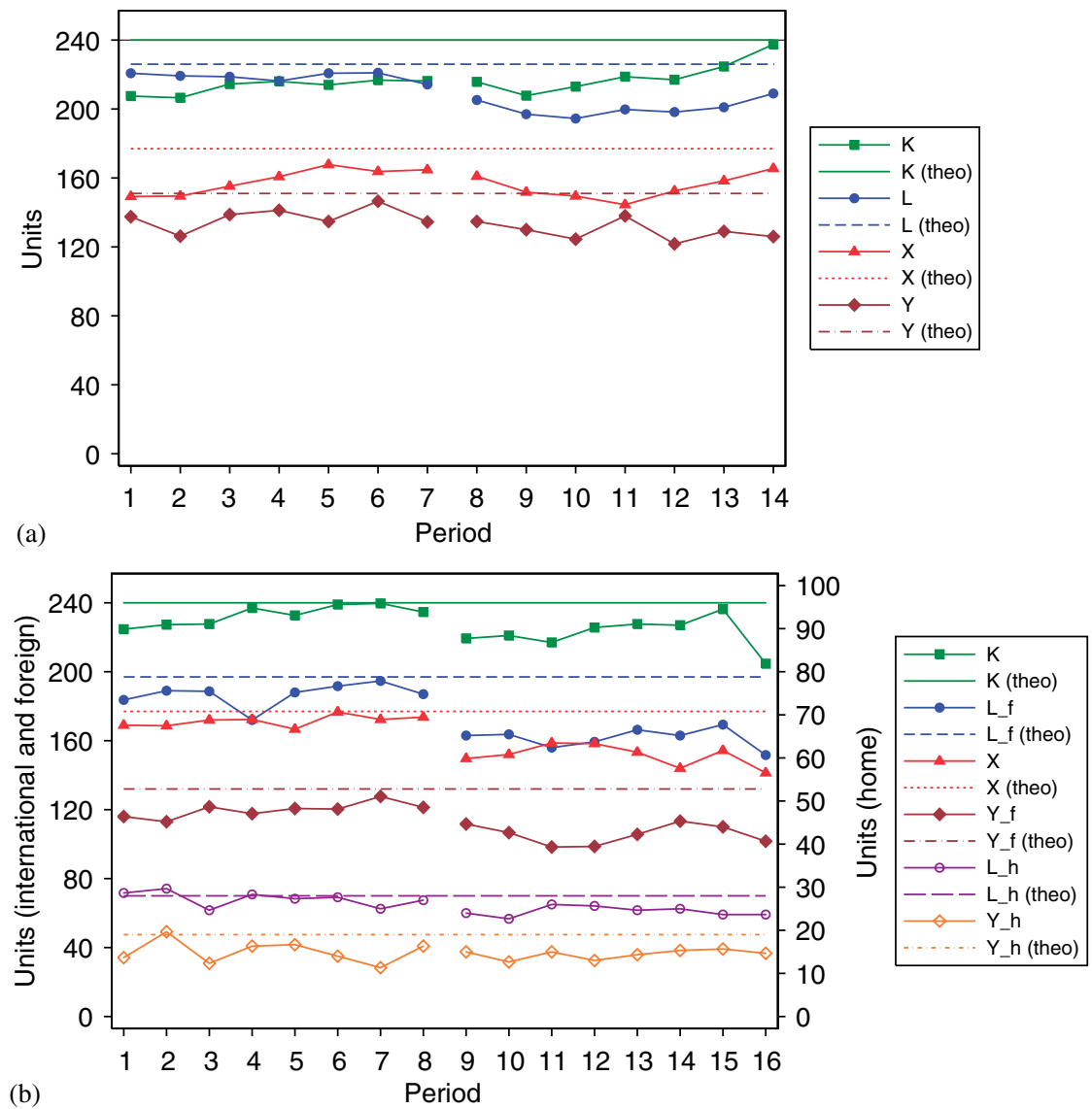

Fig. 2. Development of transacted quantities over periods (averages across sessions): (a) closed economy; (b) international economy.

with the theoretical levels. However, in many cases there also seems to be some convergence to the theoretical predictions.

Fig. 3 shows the evolution of relative prices. The figure indicates that, with the exception of $p_{y f}$ (the price of good $\mathrm{Y}$ in the foreign country), all output prices start at a higher level than predicted. Concerning the input prices it shows that wages in the closed economy and in the foreign country of the international economy are clearly too low, whereas the wage rate in the home country is too high. Interestingly, in the international economy, the capital price is far too low without showing any tendency to increase, whereas the capital price in the closed economy starts too high but steadily decreases over time. Note, that the relatively high capital price in the closed economy is accompanied by too little capital employment. As the capital price decreases employment of capital slowly converges to the full employment level (see Figs. 2(a) and 3(a)). In the international economy, with its low capital price over all periods, capital employment already starts nearby full employment and also converges quickly to it (see Figs. 2(b) and $3(b))$. 

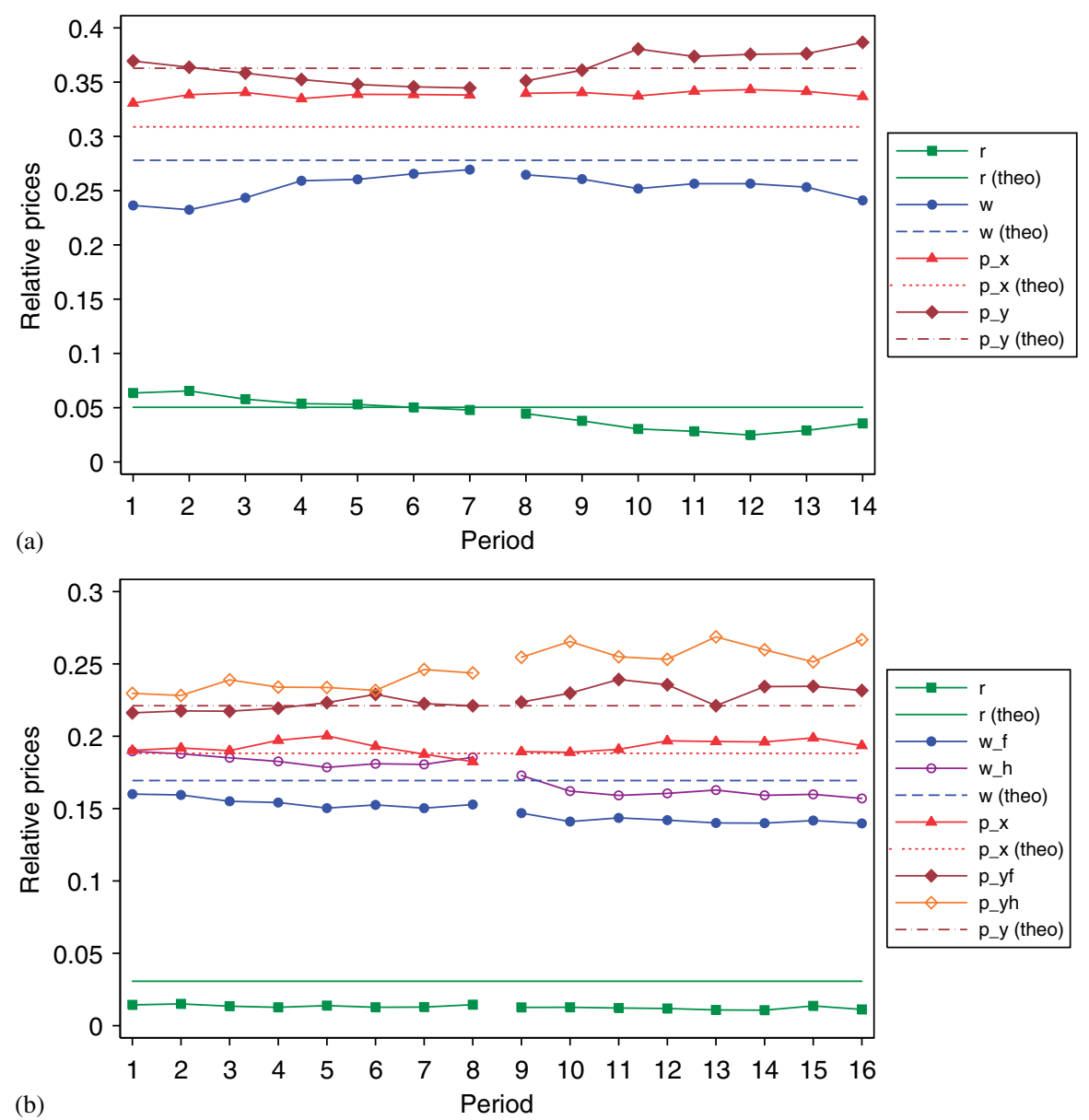

Fig. 3. Development of relative prices over periods (averages across sessions): (a) closed economy; (b) international economy.

\subsubsection{Constant tax regime}

We will now investigate more thoroughly whether the economic process indeed shows a tendency to converge towards the equilibrium predictions during the constant tax periods. To this end we have performed a statistical convergence analysis for the periods with constant tax rates, based on the following estimation model (see Noussair et al., 1995):

$$
y_{i t}=B_{11} D_{1}(1 / t)+B_{12} D_{2}(1 / t)+\cdots+B_{1 i} D_{i}(1 / t)+\cdots+B_{1 n} D_{n}(1 / t)+B_{2}(t-1) / t+u,
$$

where $y$ stands for the particular outcome (price or quantity) focused upon, $i$ denotes the experimental session, $t$ the trading period in the session, $D_{i}$ a dummy variable which is equal to 1 for $i$ and 0 otherwise, $B_{1 i}$ the session specific starting value of a possible convergence process, and $u$ the error term. Note that $B_{2}$ is the asymptote of $y$. The model assumes that for each experimental session the dependent variable in 
question may start at a different initial value $\left(B_{1 i}\right)$ but will over time converge to the common asymptote $\left(B_{2}\right)$.

In assessing whether the variable in question converges to the predicted value we are using two definitions of convergence: 'Strong convergence' and 'weak convergence' (as in Noussair et al., 1995; Lian and Plott, 1998). A variable is said to 'strongly converges' to the predicted value if $B_{2}$ is statistically not significantly different from that value.

The second definition of convergence is less demanding. The term 'weak convergence' is used when a strict majority of the starting values of the data, as measured by $B_{1 i}$, is further from the model's prediction than the asymptote, as measured by $B_{2}$. This definition is clearly weaker than 'strong convergence' but still captures some movement towards the equilibrium prediction. ${ }^{17}$ The following result summarizes the findings of this convergence analysis.

Result 2 (Constant tax regime-convergence). (i) Only a few variables strongly converge to the predicted values. Thus, from a statistical point of view the theoretical benchmark model has to be rejected.

(ii) For the closed economy weak convergence towards the theoretical predictions occurs for three of the nine variables. For the international economy weak convergence is found for eight out of 14 variables.

Support: To save on space we report here only the general findings (the detailed results of the regression analysis can be found in Appendix A (Table A1)). (i) Only one of the nine asymptotic values of the price and quantity variables concerning the closed economy is not significantly different from the values predicted by the model (at the $5 \%$ significance level). Only a slightly better outcome is obtained for the international economy, where three of the 14 values are not significantly different from the equilibrium predictions. (ii) In the closed economy the quantities of $X$ and $L$ as well as the wage rate $w$ are weakly converging. In the international economy this is the case for the quantities of $Y_{\mathrm{f}}, K, L_{\mathrm{h}}$, and $L_{\mathrm{f}}$, the relative prices $r, w_{\mathrm{h}}$, and $p_{y \mathrm{f}}$, as well as the budget surplus in the foreign country, $s_{\mathrm{f}}$.

On the one hand, the above result indicates that in a strict statistical sense the static competitive model has to be rejected as an accurate description of behavior in our experimental markets. This, however, is not too surprising since in a strict statistical sense the competitive model is often also not confirmed in simpler environments. It is also consistent with results found in other albeit less complex experimental market economies (see, e.g., Lian and Plott, 1998). On the other hand, given the complexity of our markets, the result may be viewed as surprising since it shows that there is clear order in the data and that this order moves (weakly) towards the competitive prediction. More precisely, in the sense of weak convergence, the above result gives some support for the theoretical model. It is interesting, that despite its larger complexity the international economy performs better than the closed economy, relative to the theoretical benchmark predictions. We attribute this to the stronger monetary incentives and greater experience

\footnotetext{
${ }^{17}$ Note, that 'divergence' would imply that the asymptote is further away from the predicted value (or at least not closer) than most of the initial values. Similarly, if the movement of variables would be completely random (without drift) one would expect that all initial values are similar to the asymptotic value. For this reason, 'weak convergence' requires that a strict majority of initial values is further from the model's prediction than the asymptotic value.
} 
of subjects in the international economy. The following observation, that we will elaborate on in Section 3.3, concerns the direction of the deviation of the asymptotic values from the theoretically predicted values.

Observation 1 (Constant tax regime-direction of convergence). For all input as well as output variables it holds that the asymptotic value is smaller than the predicted value. Except for $r$ in the closed economy and $w_{\mathrm{h}}$ in the international economy, this also holds for the input prices. For the output prices, on the other hand, the reverse holds, with only one exception $\left(p_{y}\right)$.

Relatively good news for the theoretical benchmark model is obtained by looking at the total welfare (earnings) of consumers in the experiments in comparison with the predicted level, denoted as 'system efficiency'. ${ }^{18}$ We focus again on the periods with constant tax rates.

Result 3 (Constant tax regime-system efficiency). In both the closed economy and the international economy system efficiency is on average around $95 \%$, and for (almost) all periods above $90 \%$.

Support: See Appendix A (Table A2).

\subsection{Unemployment, taxation, and budget deficits: The vicious circle}

In the following, any unemployment that deviates from the theoretical general equilibrium unemployment rate of $37 \%$ might be called 'disequilibrium unemployment'. However, in view of the discussion in Rogerson (1997) concerning the usefulness of these kind of labels for the phenomenon of unemployed labor units, we believe that one should use it with the necessary restraint. Additionally, here the term equilibrium refers to the benchmark model that is based on a particular set of behavioral assumptions, which are not necessarily satisfied. We therefore, refrain from using the term 'disequilibrium unemployment'.

The above results concerning weak convergence and system efficiency throw a not too negative light on the theoretical benchmark model, at least in a qualitative sense. The first part of next result, which focuses more specifically on the development of the unemployment rate under the constant tax regime, corroborates this picture. The second part of the result, however, shows that this positive result comes at the cost of persistent budget deficits.

Result 4 (Constant tax regime-labor unemployment and budget deficits). (i) In all economies the unemployment rate converges at least weakly towards the theoretical prediction from above.

(ii) All economies show convergence towards a budget deficit. Moreover, in all sessions, except for one concerning the closed economy, the budget deficits also occur in early periods.

Support: (i) The result follows straightforwardly from the convergence results (see support of Result 2(ii) and Observation 1). For details we refer the reader to the regression results for $L, L_{\mathrm{h}}$, and $L_{\mathrm{f}}$ in Appendix A (Table A1). Fig. 4(a) illustrates the development of

\footnotetext{
${ }^{18}$ The purpose of this measure, which is standard in market experiments, is not to come to unequivocal conclusions about welfare, but to get an indication of the performance of the theoretical benchmark model.
} 
the unemployment rates, averaged across experimental sessions. (ii) Fig. 4(b), showing time series for the budget surpluses averaged over the experimental sessions, clearly indicates the presence of budget deficits in all economies. Convergence analysis corroborates the visual impression. In all economies the asymptotic value of the relative budget surplus (nominal budget surplus as a fraction of national income) is significantly negative. Furthermore, in the closed economy all but one starting values are negative, and in the international economy both open economies start with a budget deficit in all three sessions. For details, see the results for $s, s_{\mathrm{h}}$, and $s_{\mathrm{f}}$ in Appendix A (Table A1).

In view of the observed deficits it is naturally to ask how the economies will perform under some fiscal discipline, by having tax rates adjust towards a balanced budget. This is what we investigate next.

\subsubsection{Variable tax regime}

In this tax regime the wage tax rate adjusts to the previous period's budget deficit (or surplus) of the tax-benefit system, such that, ceteris paribus, the budget would have been balanced. In the closed economy this happens as of period eight and in the international economy as of period nine. As the next result shows the introduction of this tax adjustment process changes the picture rather dramatically.

Result 5 (Variable tax regime-labor unemployment and budget deficits). Once the tax rate starts to adjust to the budget deficit, in all economies the deficit becomes smaller, while the tax rate as well as the unemployment rate increases to a level substantially higher than predicted by the theoretical benchmark model.

Support: See Fig. 4. Recall that the theoretically predicted tax rate is at the constant level of the initial periods shown in Fig. 4(b). Furthermore, the predicted unemployment rate is at $37 \%$ (see the straight horizontal line in Fig. 4(a)), while the deficit should be zero.

Recall from Fig. 2 that not only labor but all inputs and outputs are adversely affected by the tax adjustment, in both the closed and international economy. The same holds for our measure of system efficiency (Appendix A, Table A2). To give an impression of the effects in quantitative terms we focus on two economic measures: The unemployment rate (measured relative to equilibrium unemployment) and real GNP. ${ }^{19}$ We compare for these variables the asymptotic values of a convergence analysis applied to the constant and variable tax regime. ${ }^{20}$ This analysis shows that the relative unemployment rate increases from $3.2 \%$ to $11.3 \%$ in the closed economy, from $5.5 \%$ to $10.3 \%$ in the home country and from $3.4 \%$ to $15.0 \%$ in the foreign country of the international economy. Real GNP decreases by $5.8 \%$ in the closed economy, by $5.4 \%$ in the home country and by $18.0 \%$ in the foreign country of the international economy.

In order to investigate the role played by the wage tax more deeply, we will look at the impact of the unemployment rate in a period on the tax rate in the subsequent period and on the relation between the tax rate and unemployment rate in the same period. Note in

\footnotetext{
${ }^{19}$ For the calculation of real GNP we use the first trading period as base 'year'; that is, the respective trading period 1 prices $\left(p_{x}^{1}\right.$ and $\left.p_{y}^{1}\right)$ are used as weights for the produced quantities of $X^{t}$ and $Y^{t}$ in period $t$. Hence, real GNP in period $t$ is given by $\left(p_{x}^{t} X^{t}+p_{y}^{t} Y^{t}\right) /\left(p_{x}^{1}+p_{y}^{1}\right)$. Similar results are obtained with other periods as base year.

${ }^{20}$ The regression model for the variable tax regime is the same as for the constant tax regime except that the trading periods for the former case are redefined such that trading period 8 and 9 , respectively, becomes period 1 in the regression.
} 

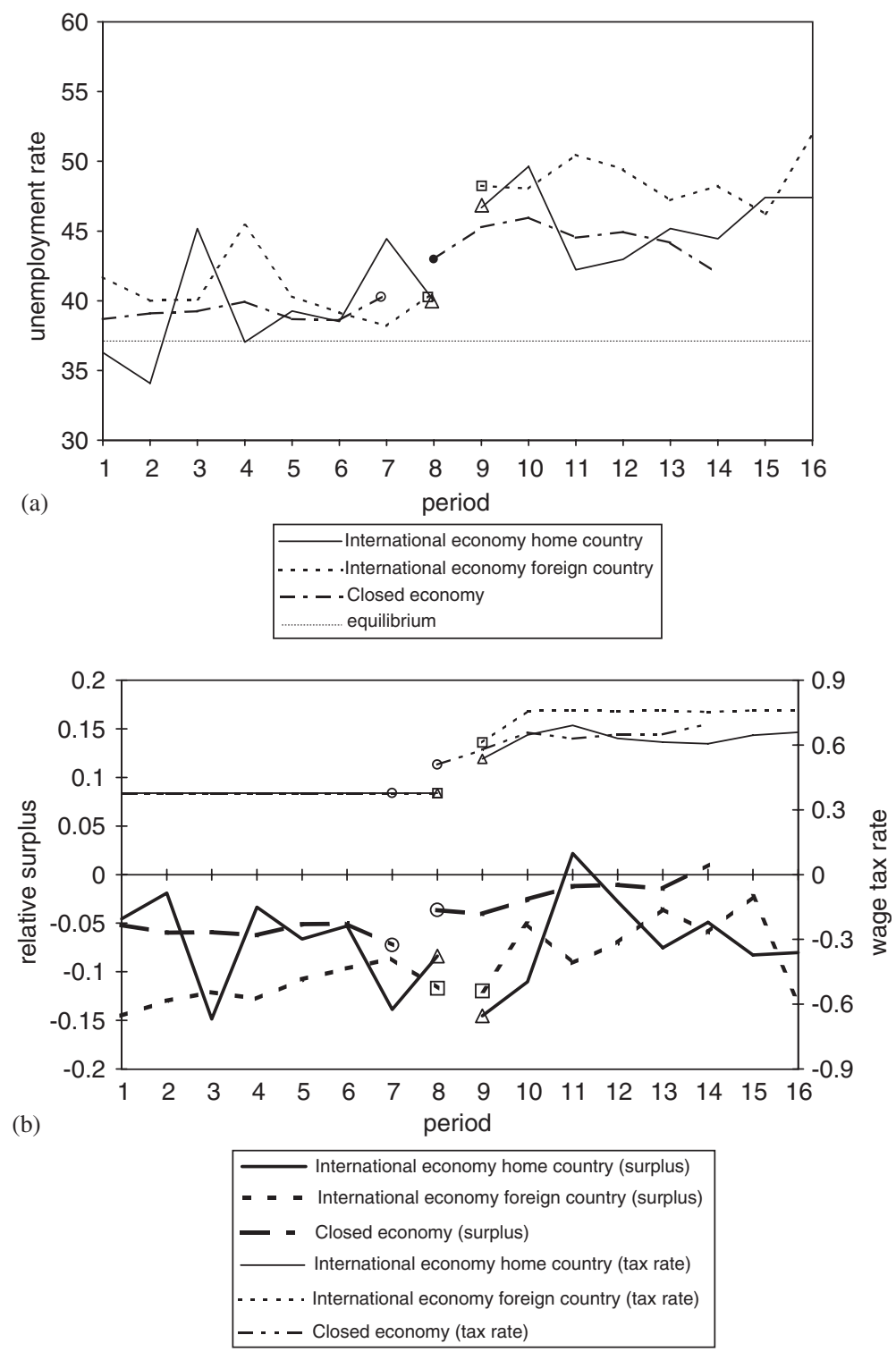

Fig. 4. Development of unemployment rates (percentage of potential labor force), budget surpluses (fraction of national income) and wage tax rates: (a) unemployment rates; (b) budget surpluses and wage tax rates.

this context that the tax adjustment rule does not necessarily imply a positive correlation between the next period's tax rate and the previous period's unemployment rate. If previous period's unemployment rate is accompanied by sufficiently high before-tax wages it is possible that a budget surplus is generated. This would imply a decrease in current period's tax rate and, hence, a negative correlation between unemployment in $t-1$ and the wage tax rate in $t$. 

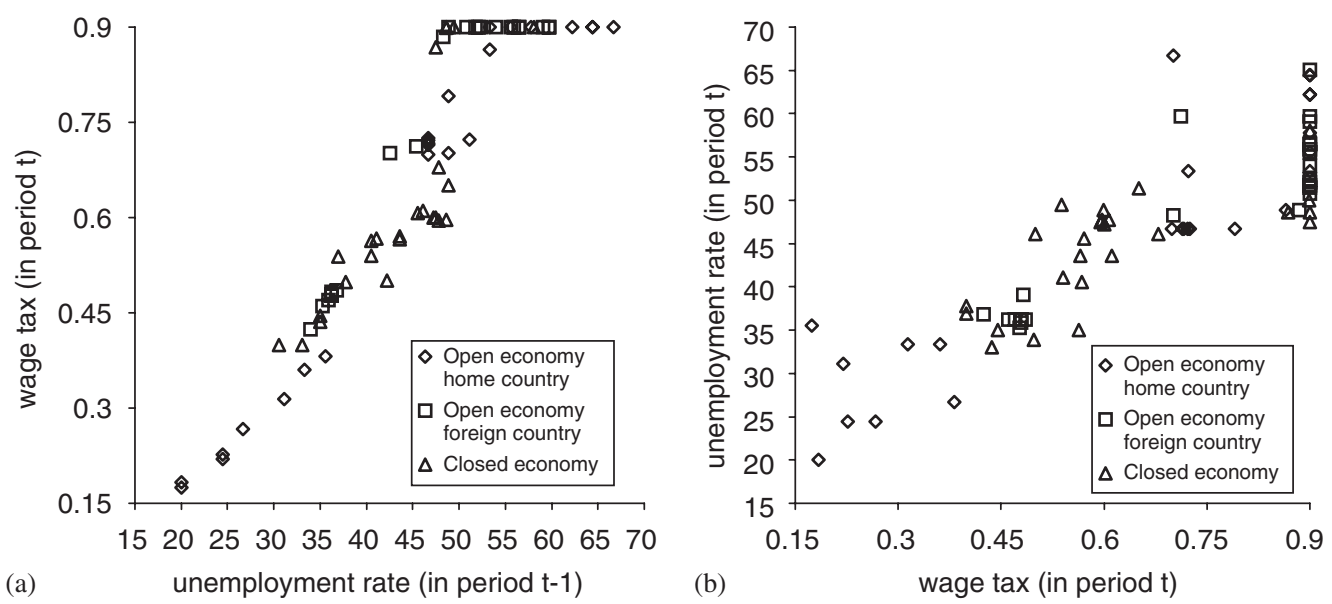

Fig. 5. The vicious circle between unemployment and wage tax rates.

Result 6 (Variable tax regime-unemployment and the wage tax rate). (i) The tax rate is significantly positively related to the unemployment rate of the previous period.

(ii) The unemployment rate in its turn is significantly positively related to the tax rate in the same period.

Support: (i) Fig. 5(a) clearly shows a positive dependence of the tax rate on the previous period unemployment rate (up to the imposed maximum rate of 0.9 , which is sometimes obtained as the upper part of the figure shows). The Spearman rank order correlation coefficients are high for all economies $(\rho \geqslant 0.92 ; p<0.001)$. (ii) Fig. 5(b) illustrates. The Spearman rank order correlation coefficient clearly shows a positive relationship for all economies $(\rho \geqslant 0.67 ; p<0.001)$.

Together, Results 5 and 6 clearly point at the existence of a vicious circle (Snower's cycle), as discussed in the Introduction. In the experimental economies, the budget deficit developed under a constant tax rate triggers a dynamic adjustment process with increasing tax rates and unemployment rates that only gradually appears to stabilize at substantially higher rates for these variables (cf. Result 5). These results are found for both the closed and the international economy, and in the latter case for both the home and the foreign country. Finally, it is noticed that the positive relationship between the unemployment rate and the wage tax rate is consistent with the conclusion that budget deficits have a beneficial impact on unemployment, as witnessed by the periods with a constant tax rate.

\subsection{A behavioral explanation of the unemployment rate}

The relatively bad performance of the economies in terms of employment (and other performance measures, like real GNP) clearly asks for an explanation. In particular, the role played by the wage tax is of interest in this respect. Given the complexity of the examined market systems we clearly cannot provide a definitive answer to this issue, at this stage. The experimental method, however, gives us the possibility to examine individual behavior more closely. We believe that the following evidence and discussion at least 
Table 4

Fraction of producers where marginal revenue product of a production factor exceeds the (after tax) input price

\begin{tabular}{lcccc}
\hline & \multirow{2}{*}{ Closed economy } & \multicolumn{2}{l}{ International economy } & \\
\cline { 3 - 5 } & & Home country & Foreign country & Both countries \\
\hline Labor & 0.52 & 0.54 & 0.62 & 0.58 \\
& $(0.20)$ & $(0.14)$ & $(0.00)$ & $(0.00)$ \\
Capital & 0.69 & 0.72 & 0.70 & 0.72 \\
& $(0.00)$ & $(0.00)$ & $(0.00)$ & $(0.00)$ \\
\hline
\end{tabular}

Note: based on average current period input and output prices and all periods; within parentheses the probability of obtaining values as least as extreme as observed when $p=0.5$; binomial test, one-sided.

reveals an under-exposed determinant of unemployment and provides an interesting and important angle for further research.

Our starting point is Observation 1 indicating that during the constant tax periods inputs and consequently outputs are below the theoretically predicted levels and tend to be accompanied by lower than predicted input prices and higher than predicted output prices. It seems that in the economies there is a downward pressure on the employment of production factors, labor as well as capital. To obtain a further piece of evidence in this respect, we examined the average per period percentage of producers for which the marginal revenue product of labor and capital exceeded the respective input price, using the average current period input and output prices. ${ }^{21}$ Accounting for errors, a percentage of $50 \%$ would be in line with (risk-neutral) profit maximizing behavior. The following is observed, however.

Observation 2. For the closed economy and the home as well as foreign country of the international economy it holds that, on average, for about $70 \%$ of the producers the marginal revenue product of capital exceeds the input price. For labor this fraction is smaller, though with approximately 55\% still above the 50\% level. This is related to the fact that for labor this fraction shows a temporary drop when the wage tax rate (which is part of the input price) starts to adjust to the budget deficit, pointing at some inertia in the behavioral adjustment process.

Support: Table 4 shows the fraction of cases in which producers employed factors such that the marginal revenue product of the factor exceeded the after tax input price. It indicates that in all economies and for both production factors this fraction is above $50 \%$. In all but two cases this difference is also statistically significant. Interestingly, the results are even somewhat stronger for the open economies where subjects (having participated in the closed economy before) were more experienced. As regards the effect of the tax rate on this fraction, in particular with respect to labor input, the following is observed. In the closed economy, for example, the fraction concerning labor temporarily drops from an average of $54(61) \%$ over the last three (all) periods of the constant tax regime to $38 \%$ in the first two periods of the variable tax regime, in which the tax rate substantially increases. It gradually increases again thereafter. This explains why - on average - the fraction is smaller for labor than for capital.

\footnotetext{
${ }^{21}$ Similar results are obtained if the average previous period product price is taken for the expected output price.
} 
Together with Observation 1 this observation supports the view that producers' reluctance to buy inputs is key for explaining the high unemployment rate. It is important to note that it is not a lack of labor supply that can account for the higher than predicted unemployment level. Using the theoretical labor supply function-for each consumer and trading period - it turns out that a great majority of the consumers actually supplied too much labor at current period prices. ${ }^{22}$

In our view a key factor in the explanation of the downward pressure on input demand seems to be that in a real economy-like in the lab-producers are facing a risk when buying inputs, which is not accounted for in a general equilibrium model. This risk is due to uncertainty about the prices and thus revenues that the goods produced with the inputs will make in the output markets. The fact that producers are facing this risk, in combination with risk or ambiguity aversion, can explain the reluctance of producers to employ 'enough' labor and capital, as well as the observed downward pressure on input prices and upward pressure on output prices (see Observation 1). This view is also supported by the following observation:

Observation 3. In a majority of markets factor employment is negatively affected by output price uncertainty (measured by the dispersion of output prices in the previous period). This effect is particularly pronounced in the open economy with experienced traders.

Support: We have correlated the standard deviations of output transaction prices in period $t-1$ in sector $X$ and sector $Y$ per economy and country with the factor employment in period $t$ in the respective sector. In 8 out of 12 cases the Spearman rank order correlation coefficient is negative. In five cases the negative correlations are statistically significant ( $p<0.05$, one-sided tests). The non-negative correlation coefficients are never significantly different from zero. More specifically, in the closed economy none of the correlations is significant ( $p>0.0750$; one-sided tests). In the open economy there is a statistically significantly negative correlation in sector $X$ of the small country with respect to capital and labor $(\rho \leqslant-0.30, p \leqslant 0.0225$; one-sided tests). In the large country these correlations are significant in sector $X$ with respect to labor and in sector $Y$ with respect to capital and labor $(\rho \leqslant-0.27, p \leqslant 0.0353$; one-sided tests). In the remaining three markets the correlation coefficients are not significantly different from zero $(p>0.2855$; one-sided tests).

Interestingly, a similar risk-compensated price mechanism has been observed by Noussair et al. $(1995,2003)$ in their experimental investigation of patterns of international trade. It is important to note that in their study simultaneous input and output markets are investigated. This suggests that the mechanism is also at work when the sequentiality between input and output markets is minimized. ${ }^{23}$ Furthermore, some theoretical (albeit

\footnotetext{
${ }^{22}$ For the closed as well as the small and large country of the international economy, this happens (averaged over consumers and periods) in at least $80 \%$ of the cases, for both the constant and the variable tax regime. These results are significantly different from $50 \%$, using a binomial test $(p<0.001$, one-sided). We can think of two factors that may have biased consumer behavior in this direction. First, the relatively small weight (1/9) attached to leisure in the utility function may have played a role here (see Table 1). Second, the fact that the labor supply function is steep at the low wage rates (close to the minimum level of the unemployment benefit) that subjects were confronted with may have led to 'overshooting' due to errors.

${ }^{23}$ Hey and di Cagno (1998), investigating experimentally two sequential double auction markets, also report as a general finding that not enough trade took place compared with the competitive equilibrium predictions.
} 
partial equilibrium) studies exist showing that price uncertainty will indeed reduce factor demand (see Batra and Ullah, 1974; Hartman, 1975, 1976; Holthausen, 1976) and investment (Saltari and Ticchi, 2005) by risk-averse competitive firms.

A number of empirical studies support the assumption of risk-averse behavior of firms. For instance, Gunjal and Legault (1995) show risk-aversion by firms and according to Stiglitz (1999, p. 254): "There is by now a large body of literature arguing that normally firms act in a risk averse manner (...)". Zhang (1998, p. 1753) notes: "Investors of all types generally exhibit aversion to risk". Furthermore, an interesting study by Brockhaus (1982) suggests that there is no difference with respect to risk-averse behavior between producers ('entrepreneurs' and managers) and the population at large (see also Ghosal, 1995). ${ }^{24}$ Unfortunately, so far field empirical studies addressing the consequences of risk-averse behavior for input demand appear to be lacking.

A remaining question is if the wage tax has any effects on output price uncertainty. The following observation provides an answer.

Observation 4. An increase in the wage tax rate significantly increases output price uncertainty (measured by the dispersion of output prices in the same period), in most cases.

Support: For the $X$ and the $Y$ sectors in the closed economy and both countries of the open economy, we have correlated the wage tax rates in a period $t$ with the standard deviation of nominal output transaction prices in the same period. Since wage tax rates change only in the variable tax regime observations from this regime are used in the correlation statistics. In turns out that in all but two of the six cases the Spearman rank order correlation coefficient is significantly positive $(p<0.05$, all tests one-sided). More specifically, $\rho=0.57(p=0.0019)$ and $\rho=0.52(p=0.0050)$ for sector $X$ and $Y$, respectively, in the small country of the open economy, $\rho=0.43(p=0.0019)$ for sector $X$ in the large country of the open economy, and $\rho=0.39(p=0.0310)$ for sector $Y$ in the closed economy. In the remaining two cases - sector $Y$ in the large country of the open economy and sector $X$ of the closed economy-there is also a positive (albeit statistically insignificant) correlation between the wage tax rate and output price uncertainty.

In our view Observations 3 and 4 together strongly suggest that price uncertainty triggered by the wage tax is indeed an important explanatory factor for the reluctance of producers to employ labor and capital.

Although further empirical as well as theoretical research is needed to establish the precise power of the offered explanation, it points at an important and under-exposed determinant of unemployment. Moreover, it has an important bearing on the debate concerning the pernicious character of wage taxation (and, more generally, the taxation of inputs). If producers are reluctant to buy inputs due to uncertainty about output prices, having to pay taxes up-front seems to exacerbate the negative effects on employment. Note that loss aversion, as in prospect theory (Kahneman and Tversky, 1979), would make this

\footnotetext{
${ }^{24} \mathrm{~A}$ related area of research focuses on the effect of macro-economic uncertainty on private investment. Only a few empirical studies exist, typically showing a negative effect (of inflation, for instance; see Aizenman and Marion, 1993; Brunetti and Weder, 1998).
} 
negative effect even stronger. From this perspective, shifting taxation from labor to production or sales - which effectively makes the government share the risk faced by the producer - would be an alternative worth investigating.

\section{Concluding discussion}

For the closed as well as the small and the large country of the international economy, we have found evidence for negative economic effects of wage taxation as a means of financing unemployment benefits. Our results provide empirical support for a vicious circle in the dynamic interaction between the wage tax and the unemployment rate. Furthermore, it turned out that employment is boosted by allowing a deficit in the budget of the tax-benefit system. Keeping the tax rate constant at the level predicted by the competitive equilibrium model, convergence towards the competitive equilibrium is observed for many variables. However, this development is accompanied by economically significant budget deficits. Once the wage tax is forced to adjust in the direction of a budget balance the employment level, as well as real GDP and other indicators of economic performance, gradually tend to stabilize at a level that substantially falls short of the equilibrium prediction.

An important observation in this context is that there appears to be downward pressure on the employment of production factors, which is not accounted for in existing general equilibrium models. The uncertainty risk or ambiguity averse producers are facing when buying inputs before precisely knowing what they will make for their outputs can explain this phenomenon. Because of the uncertainty producers restrict the purchase of inputs, which restricts outputs. Consequently, there is a tendency for input prices to be lower, and for output prices to be higher than the equilibrium predictions. It is consistent with this socalled risk-compensated price mechanism that a wage tax exacerbates these effects.

Our findings suggest that policymakers relying on the outcomes of (theoretical) models neglecting this mechanism would underestimate the negative effects of wage taxation. According to the European Commission (1994), plans for an alternative, employment friendlier fiscal structure deserve greater attention and serious study. Our study suggests that shifting taxation from labor, and more generally any kind of inputs, to outputs is worthwhile to be investigated. Another interesting issue for future research would be to investigate the effects of adjusting the unemployment benefit instead of the wage tax to balance the budget (cf. Rochetau, 1999).

From a theoretical perspective, the contribution of our experimental study is twofold. Firstly, it suggests that a better understanding of the determinants of unemployment can be obtained by allowing for output price uncertainty and risk or ambiguity aversion in economic models. In this respect, this paper provides support for some existing partial equilibrium models bearing this out. By neglecting these issues, present general equilibrium models seem to foster a too rosy view of the economic effects of wage taxation. Secondly, and more generally, the results of our experiment suggest a new perspective on the micro foundation of macroeconomics. In simple market experiments it was already shown that behavioral aspects should not be disregarded (see e.g. Myagkov and Plott, 1997 on loss aversion, Ball et al., 2001 on status). Our experiment adds that behavioral factors can also be relevant for the outcome in more complex market environments. This indicates that the significance of other features (like norms, cognitive limitations, emotions, and bounded rationality) in complex settings can be fruitfully investigated with the help of laboratory 
experimentation. Further empirical regularities found by these experiments can generate new theoretical research questions and lead to new and better micro- and macro-economic general equilibrium models.

From a broader methodological point of view, the technology developed for running macro-economic experiments opens up the possibility to study many other important issues in the lab, like public debt or the impact of labor market institutions, for example. In light of the findings obtained so far, macro-economic experiments seem to offer an interesting and challenging research tool which complements the more traditional theoretical and field empirical analysis.

\section{Acknowledgements}

Financial support by the Ministry and comments and suggestions by its Steering Committee are gratefully acknowledged. We are very thankful to Frans van Dijk and Jorgen Wit who were both involved in the experimental design of the project, and, in addition, to Jorgen Wit for the computation of the equilibria of the theoretical model used in the project. Our gratitude furthermore goes to Jos Theelen for the development of the software, and to G. Cotteleer, J.H.H. Notmijer, and M. Smits for their assistance in running the experiments. We are also grateful for the very useful suggestions and remarks of two anonymous reviewers of this journal and the comments by participants in seminars and conferences in Bonn, Frankfurt, Innsbruck, Rhodos, Stockholm, St. Gallen, Tilburg, Lake Tahoe, Bari, Groningen, Munich, New York, and Barcelona, where we reported on results of the project. The paper is part of the EU-TMR Research Network ENDEAR (FMRX-CT98-0238). The usual disclaimer applies.

\section{Appendix A. Results of convergence analysis}

Table A1 summarizes the results of our convergence analysis described in Result 2 and some further observations and results thereafter for the real variables, the relative prices,

Table A1

Convergence results for constant tax periods

\begin{tabular}{lcccccccc}
\hline Variable & $B_{11}$ & $B_{12}$ & $B_{13}$ & $B_{14}$ & $B_{2}$ & Prediction & $p$-Value & Wald's $\chi^{2}$ \\
\hline \multicolumn{7}{l}{ Closed economy } \\
$X$ & 180.6 & 121.4 & 142.0 & 144.5 & 163.1 & 177 & 0.001 & 27681.6 \\
& $(8.24)$ & $(16.74)$ & $(3.54)$ & $(13.73)$ & $(4.41)$ & & & \\
$Y$ & 154.8 & 120.5 & 103.1 & 158.5 & 138.9 & 151 & 0.000 & 11865.4 \\
$K$ & $(4.33)$ & $(8.14)$ & $(6.36)$ & $(14.73)$ & $(3.05)$ & & & \\
& 219.1 & 221.8 & 196.6 & 185.9 & 216.1 & 240 & 0.000 & 34287.2 \\
$L$ & $(8.95)$ & $(8.08)$ & $(3.75)$ & $(9.04)$ & $(2.43)$ & & & \\
& 252.2 & 208.5 & 189.6 & 233.2 & 214.6 & 226 & 0.011 & 10241.6 \\
$r$ & $(9.74)$ & $(19.78)$ & $(5.09)$ & $(16.65)$ & $(4.50)$ & & & \\
& 0.0800 & 0.0539 & 0.0581 & 0.0933 & 0.0588 & 0.0504 & 0.058 & 784.7 \\
$w$ & $(0.0044)$ & $(0.0182)$ & $(0.0069)$ & $(0.0118)$ & $(0.0044)$ & & & \\
& 0.2449 & 0.2632 & 0.2273 & 0.2094 & 0.2609 & 0.2978 & 0.000 & 10289.6
\end{tabular}


Table A1 (continued)

\begin{tabular}{|c|c|c|c|c|c|c|c|c|}
\hline Variable & $B_{11}$ & $B_{12}$ & $B_{13}$ & $B_{14}$ & $B_{2}$ & Prediction & $p$-Value & Wald's $\chi^{2}$ \\
\hline$p_{x}$ & $\begin{array}{c}0.2911 \\
(0.0053)\end{array}$ & $\begin{array}{c}0.3512 \\
(0.0051)\end{array}$ & $\begin{array}{c}0.3292 \\
(0.0034)\end{array}$ & $\begin{array}{c}0.3190 \\
(0.0065)\end{array}$ & $\begin{array}{c}0.3370 \\
(0.0017)\end{array}$ & 0.3088 & 0.000 & 135054.6 \\
\hline$p_{y}$ & $\begin{array}{c}0.3670 \\
(0.0086)\end{array}$ & $\begin{array}{c}0.3790 \\
(0.0182)\end{array}$ & $\begin{array}{c}0.3785 \\
(0.0054)\end{array}$ & $\begin{array}{c}0.6288 \\
(0.0073)\end{array}$ & $\begin{array}{c}0.3444 \\
(0.0044)\end{array}$ & 0.3628 & 0.000 & 32611.1 \\
\hline$s$ & $\begin{array}{c}0.0147 \\
(0.0224)\end{array}$ & $\begin{array}{c}-0.0827 \\
(0.0422)\end{array}$ & $\begin{array}{r}-0.0981 \\
(0.0124)\end{array}$ & $\begin{array}{r}-0.0193 \\
(0.0329)\end{array}$ & $\begin{array}{r}-0.0657 \\
(0.0099)\end{array}$ & 0 & 0.000 & 271.7 \\
\hline \multicolumn{9}{|c|}{ International economy } \\
\hline$X$ & $\begin{array}{l}171.9 \\
\quad(5.97)\end{array}$ & $\begin{array}{l}129.0 \\
(8.22)\end{array}$ & $\begin{array}{l}183.6 \\
(14.59)\end{array}$ & & $\begin{array}{l}164.7 \\
(3.43)\end{array}$ & 177 & 0.000 & 5561.2 \\
\hline$Y_{\mathrm{h}}$ & $\begin{array}{l}15.4 \\
(2.82)\end{array}$ & $\begin{array}{l}14.1 \\
(2.98)\end{array}$ & $\begin{array}{l}18.9 \\
(1.72)\end{array}$ & & $\begin{array}{l}14.8 \\
(0.87)\end{array}$ & 19 & 0.000 & 1135.4 \\
\hline$Y_{\mathrm{f}}$ & $\begin{array}{c}89.9 \\
(12.22)\end{array}$ & $\begin{array}{l}137.1 \\
(10.97)\end{array}$ & $\begin{array}{l}113.7 \\
(3.38)\end{array}$ & & $\begin{array}{l}120.3 \\
\quad(2.43)\end{array}$ & 132 & 0.000 & 11468.0 \\
\hline$K$ & $\begin{array}{l}231.5 \\
\quad(8.92)\end{array}$ & $\begin{array}{r}209.2 \\
\quad(5.99)\end{array}$ & $\begin{array}{r}230.7 \\
(4.32)\end{array}$ & & $\begin{array}{r}236.1 \\
\quad(3.04)\end{array}$ & 240 & 0.204 & 18131.7 \\
\hline$L_{\mathrm{h}}$ & $\begin{array}{l}28.2 \\
(2.48)\end{array}$ & $\begin{array}{l}24.9 \\
(3.51)\end{array}$ & $\begin{array}{l}31.8 \\
(4.58)\end{array}$ & & $\begin{array}{l}25.5 \\
(1.43)\end{array}$ & 28 & 0.084 & 811.7 \\
\hline$L_{\mathrm{f}}$ & $\begin{array}{l}167.0 \\
(12.13)\end{array}$ & $\begin{array}{l}175.5 \\
(11.26)\end{array}$ & $\begin{array}{l}204.6 \\
(14.19)\end{array}$ & & $\begin{array}{r}186.2 \\
\quad(5.27)\end{array}$ & 197 & 0.041 & 2700.0 \\
\hline$r$ & $\begin{array}{c}0.0141 \\
(0.0021)\end{array}$ & $\begin{array}{c}0.0164 \\
(0.0011)\end{array}$ & $\begin{array}{c}0.0201 \\
(0.0030)\end{array}$ & & $\begin{array}{c}0.0169 \\
(0.0013)\end{array}$ & 0.0307 & 0.000 & 375.4 \\
\hline$w_{\mathrm{h}}$ & $\begin{array}{c}0.1903 \\
(0.0110)\end{array}$ & $\begin{array}{c}0.2010 \\
(0.0050)\end{array}$ & $\begin{array}{c}0.1748 \\
(0.0033)\end{array}$ & & $\begin{array}{c}0.1825 \\
(0.0039)\end{array}$ & 0.1694 & 0.001 & 4962.4 \\
\hline$w_{\mathrm{f}}$ & $\begin{array}{c}0.1796 \\
(0.0053)\end{array}$ & $\begin{array}{c}0.1426 \\
(0.0048)\end{array}$ & $\begin{array}{c}0.1547 \\
(0.0067)\end{array}$ & & $\begin{array}{c}0.1501 \\
(0.0029)\end{array}$ & 0.1694 & 0.000 & 5419.4 \\
\hline$p_{x}$ & $\begin{array}{c}0.1764 \\
(0.0144)\end{array}$ & $\begin{array}{c}0.2283 \\
(0.0039)\end{array}$ & $\begin{array}{c}0.1869 \\
(0.0082)\end{array}$ & & $\begin{array}{c}0.2001 \\
(0.0057)\end{array}$ & 0.1882 & 0.038 & 5628.6 \\
\hline$p_{y \mathrm{~h}}$ & $\begin{array}{c}0.2277 \\
(0.0171)\end{array}$ & $\begin{array}{c}0.2177 \\
(0.0110)\end{array}$ & $\begin{array}{c}0.2500 \\
(0.0120)\end{array}$ & & $\begin{array}{c}0.2390 \\
(0.0068)\end{array}$ & 0.2211 & 0.009 & 2016.5 \\
\hline$p_{y \mathrm{f}}$ & $\begin{array}{c}0.2107 \\
(0.0181)\end{array}$ & $\begin{array}{c}0.2059 \\
(0.0102)\end{array}$ & $\begin{array}{c}0.2446 \\
(0.0037)\end{array}$ & & $\begin{array}{c}0.2211 \\
(0.0024)\end{array}$ & 0.2211 & 0.985 & 30222.6 \\
\hline$s_{\mathrm{h}}$ & $\begin{array}{r}-0.0927 \\
(0.0676)\end{array}$ & $\begin{array}{r}-0.0895 \\
(0.0804)\end{array}$ & $\begin{array}{r}-0.0070 \\
(0.1129)\end{array}$ & & $\begin{array}{r}-0.1409 \\
(0.0345)\end{array}$ & 0 & 0.000 & 29.6 \\
\hline$s_{\mathrm{f}}$ & $\begin{array}{r}-0.2724 \\
(0.0467)\end{array}$ & $\begin{array}{r}-0.1578 \\
(0.0154)\end{array}$ & $\begin{array}{r}-0.0425 \\
(0.0539)\end{array}$ & & $\begin{array}{r}-0.1174 \\
(0.0108)\end{array}$ & 0 & 0.000 & 887.3 \\
\hline
\end{tabular}

Note: $X, Y, Y_{\mathrm{h}}, Y_{\mathrm{f}}$ denote sales in sectors $X$ and $Y ; K$ denotes employed capital; $L, L_{\mathrm{h}}, L_{\mathrm{f}}$ are employed units of labor; $r$ is the relative price of capital, $w, w_{\mathrm{h}}, w_{1}$ are the relative wages; $p_{x}$ is the relative price of $X ; p_{y}, p_{y \mathrm{~h}}, p_{y \mathrm{f}}$ are the relative prices of $Y ; s, s_{\mathrm{h}}, s_{\mathrm{f}}$ are budget surpluses relative to gross national income; the subscripts $\mathrm{h}$ and $\mathrm{f}$ in the international economy denote the home and the foreign country, respectively. Standard errors in parentheses, corrected for session specific heteroskedasticity and AR(1).

and the relative surpluses. The variables are described at the bottom of the table. The reported $p$-value results from a two-sided F-test comparing $B_{2}$ with the predicted value 'Prediction'.

Table A2 reports 'system efficiency', defined as the total earnings of consumers as a percentage of the theoretically predicted earnings, for all sessions and all periods as well as the averages across the constant tax periods, the dynamic tax periods, and all periods. 
Table A2

System efficiency: Sum of consumers welfare relative to theoretical prediction (in percent)

\begin{tabular}{|c|c|c|c|c|c|c|c|c|c|c|c|c|c|}
\hline \multirow[t]{3}{*}{ Period } & \multicolumn{4}{|c|}{ Closed economy } & \multicolumn{9}{|c|}{ International economy } \\
\hline & \multirow[t]{2}{*}{ CE01 } & \multirow[t]{2}{*}{ CE02 } & \multirow[t]{2}{*}{ CE03 } & \multirow[t]{2}{*}{ CE04 } & \multicolumn{3}{|l|}{ OE01 } & \multicolumn{3}{|l|}{ OE02 } & \multicolumn{3}{|l|}{ OE03 } \\
\hline & & & & & Home & Foreign & Total & Home & Foreign & Total & Home & Foreign & Total \\
\hline 1 & 97.0 & 92.2 & 90.0 & 94.7 & 61.3 & 93.6 & 83.0 & 94.5 & 95.2 & 95.0 & 97.7 & 98.7 & 98.4 \\
\hline 2 & 98.4 & 88.0 & 91.8 & 92.6 & 106.3 & 91.2 & 96.1 & 96.4 & 96.9 & 96.7 & 101.0 & 96.6 & 98.0 \\
\hline 3 & 99.0 & 92.0 & 92.4 & 97.1 & 89.8 & 95.7 & 93.8 & 61.9 & 95.1 & 84.3 & 97.6 & 98.0 & 97.9 \\
\hline 4 & 99.4 & 92.4 & 95.1 & 99.2 & 88.7 & 95.1 & 93.0 & 96.9 & 96.9 & 96.9 & 93.8 & 98.9 & 97.2 \\
\hline 5 & 97.6 & 92.5 & 94.9 & 97.7 & 98.8 & 93.9 & 95.5 & 93.8 & 97.5 & 96.3 & 101.3 & 99.0 & 99.8 \\
\hline 6 & 96.7 & 91.2 & 95.3 & 99.6 & 95.5 & 96.0 & 95.8 & 95.2 & 97.5 & 96.8 & 92.9 & 98.9 & 96.9 \\
\hline 7 & 96.7 & 91.9 & 93.6 & 95.2 & 98.9 & 93.5 & 95.3 & 61.6 & 98.3 & 86.3 & 94.9 & 98.7 & 97.4 \\
\hline 8 & 96.8 & 92.8 & 95.4 & 92.8 & 94.2 & 96.8 & 96.0 & 95.8 & 96.9 & 96.5 & 100.2 & 98.6 & 99.1 \\
\hline 9 & 94.5 & 91.3 & 95.7 & 93.5 & 82.2 & 91.3 & 88.3 & 83.9 & 95.1 & 91.4 & 65.5 & 98.6 & 87.8 \\
\hline 10 & 80.2 & 92.4 & 94.9 & 88.3 & 78.2 & 90.6 & 86.6 & 86.2 & 94.5 & 91.8 & 92.9 & 98.2 & 96.5 \\
\hline 11 & 96.6 & 88.9 & 95.3 & 93.3 & 83.0 & 94.0 & 90.4 & 89.2 & 90.0 & 89.7 & 98.2 & 98.9 & 98.7 \\
\hline 12 & 95.6 & 89.5 & 94.4 & 92.0 & 82.4 & 93.7 & 90.0 & 77.4 & 87.9 & 84.4 & 101.4 & 98.7 & 99.6 \\
\hline 13 & 96.6 & & 94.1 & 93.3 & 77.6 & 93.8 & 88.5 & 87.6 & 94.0 & 91.9 & 101.3 & 98.3 & 99.3 \\
\hline 14 & 97.3 & & & 92.1 & 84.3 & 94.8 & 91.3 & 87.9 & 93.0 & 91.4 & 97.4 & 98.6 & 98.2 \\
\hline 15 & & & & & 88.9 & 94.9 & 93.0 & 93.0 & 93.8 & 93.6 & 97.7 & 98.4 & 98.1 \\
\hline 16 & & & & & 83.8 & 95.0 & 91.4 & 70.6 & 89.5 & 83.3 & 96.7 & 97.3 & 97.1 \\
\hline \multicolumn{14}{|l|}{ Averages across: } \\
\hline Constant tax periods & 97.8 & 91.4 & 93.4 & 96.6 & 91.7 & 94.5 & 93.6 & 87.0 & 96.8 & 93.6 & 97.4 & 98.4 & 98.1 \\
\hline Variable tax periods & 93.9 & 91.0 & 95.0 & 92.2 & 82.5 & 93.5 & 89.9 & 84.5 & 92.2 & 89.7 & 93.9 & 98.4 & 96.9 \\
\hline All periods & 95.9 & 91.3 & 94.1 & 94.4 & 87.1 & 94.0 & 91.8 & 85.7 & 94.5 & 91.6 & 95.7 & 98.4 & 97.5 \\
\hline
\end{tabular}




\section{Appendix B. Redemption values and production schedules}

This appendix contains examples of tables showing the redemption values of consumers in the (large) foreign country and the production schedule of an $X$-producer in the (small) home country of the international economy. The redemption values for consumers in the home country of the international economy and the closed economy and for the other producer types are similar. (Note, that for publishing technical reasons the schedules reproduced here to not exactly resemble the original versions used in the experiment.) The complete set of instructions including all tables is available upon request from the authors.

\section{B.1. Redemption value table of a consumer in the foreign country of the international economy}

A production schedule for Type-I (consumer) $\mathrm{X}$ is given in Table B1.

Table B1

Redemption values table Type-I

\begin{tabular}{|c|c|c|c|c|c|c|}
\hline Unit & $\begin{array}{l}\mathrm{V} \text { unit } \\
\text { value }\end{array}$ & $\begin{array}{l}\mathrm{V} \text { total } \\
\text { value }\end{array}$ & $\begin{array}{l}\mathrm{X} \text { unit } \\
\text { value }\end{array}$ & $\begin{array}{l}\mathrm{X} \text { total } \\
\text { value }\end{array}$ & $\begin{array}{l}\mathrm{Y} \text { unit } \\
\text { value }\end{array}$ & $\begin{array}{l}Y \text { total } \\
\text { value }\end{array}$ \\
\hline
\end{tabular}

\begin{tabular}{|c|c|c|c|c|c|c|}
\hline 1 & 0.00 & 0.00 & 0.00 & 0.00 & 0.00 & 0.00 \\
\hline 2 & 4.33 & 4.33 & 17.33 & 17.33 & 17.33 & 17.33 \\
\hline 3 & 2.53 & 6.87 & 10.14 & 27.47 & 10.14 & 27.47 \\
\hline 4 & 1.80 & 8.66 & 7.19 & 34.66 & 7.19 & 34.66 \\
\hline 5 & 1.39 & 10.06 & 5.58 & 40.24 & 5.58 & 40.24 \\
\hline 6 & 1.14 & 11.20 & 4.56 & 44.79 & 4.56 & 44.79 \\
\hline 7 & 0.96 & 12.16 & 3.85 & 48.65 & 3.85 & 48.65 \\
\hline 8 & 0.83 & 13.00 & 3.34 & 51.99 & 3.34 & 51.99 \\
\hline 9 & 0.74 & 13.73 & 2.94 & 54.93 & 2.94 & 54.93 \\
\hline 10 & 0.66 & 14.39 & 2.63 & 57.56 & 2.63 & 57.56 \\
\hline 11 & 0.60 & 14.99 & 2.38 & 59.95 & 2.38 & 59.95 \\
\hline 12 & 0.54 & 15.53 & 2.18 & 62.12 & 2.18 & 62.12 \\
\hline 13 & 0.50 & 16.03 & 2.00 & 64.12 & 2.00 & 64.12 \\
\hline 14 & 0.46 & 16.49 & 1.85 & 65.98 & 1.85 & 65.98 \\
\hline 15 & 0.43 & 16.93 & 1.72 & 67.70 & 1.72 & 67.70 \\
\hline 16 & 0.40 & 17.33 & 1.61 & 69.31 & 1.61 & 69.31 \\
\hline 17 & 0.38 & 17.71 & 1.52 & 70.83 & 1.52 & 70.83 \\
\hline 18 & 0.36 & 18.06 & 1.43 & 72.26 & 1.43 & 72.26 \\
\hline 19 & 0.34 & 18.40 & 1.35 & 73.61 & 1.35 & 73.61 \\
\hline 20 & 0.32 & 18.72 & 1.28 & 74.89 & 1.28 & 74.89 \\
\hline 21 & 0.30 & 19.03 & 1.22 & 76.11 & 1.22 & 76.11 \\
\hline 22 & 0.29 & 19.32 & 1.16 & 77.28 & 1.16 & 77.28 \\
\hline 23 & 0.28 & 19.60 & 1.11 & 78.39 & 1.11 & 78.39 \\
\hline 24 & 0.27 & 19.86 & 1.06 & 79.45 & 1.06 & 79.45 \\
\hline 25 & 0.26 & 20.12 & 1.02 & 80.47 & 1.02 & 80.47 \\
\hline 26 & 0.25 & 20.36 & 0.98 & 81.45 & 0.98 & 81.45 \\
\hline 27 & 0.24 & 20.60 & 0.94 & 82.40 & 0.94 & 82.40 \\
\hline 28 & 0.23 & 20.83 & 0.91 & 83.31 & 0.91 & 83.31 \\
\hline 29 & 0.22 & 21.05 & 0.88 & 84.18 & 0.88 & 84.18 \\
\hline 30 & 0.21 & 21.26 & 0.85 & 85.03 & 0.85 & 85.03 \\
\hline 31 & 0.20 & 21.46 & 0.82 & 85.85 & 0.82 & 85.85 \\
\hline 32 & 0.20 & 21.66 & 0.79 & 86.64 & 0.79 & 86.64 \\
\hline
\end{tabular}


Table B1 (continued)

\begin{tabular}{|c|c|c|c|c|c|c|}
\hline Unit & $\begin{array}{l}\text { V unit } \\
\text { value }\end{array}$ & $\begin{array}{l}\mathrm{V} \text { total } \\
\text { value }\end{array}$ & $\begin{array}{l}\mathrm{X} \text { unit } \\
\text { value }\end{array}$ & $\begin{array}{l}\mathrm{X} \text { total } \\
\text { value }\end{array}$ & $\begin{array}{l}\text { Y unit } \\
\text { value }\end{array}$ & $\begin{array}{l}\text { Y total } \\
\text { value }\end{array}$ \\
\hline 33 & 0.19 & 21.85 & 0.77 & 87.41 & 0.77 & 87.41 \\
\hline 34 & 0.19 & 22.04 & 0.75 & 88.16 & 0.75 & 88.16 \\
\hline 35 & 0.18 & 22.22 & 0.72 & 88.88 & 0.72 & 88.88 \\
\hline 36 & 0.18 & 22.40 & 0.70 & 89.59 & 0.70 & 89.59 \\
\hline 37 & 0.17 & 22.57 & 0.68 & 90.27 & 0.68 & 90.27 \\
\hline 38 & 0.17 & 22.73 & 0.67 & 90.94 & 0.67 & 90.94 \\
\hline 39 & 0.16 & 22.90 & 0.65 & 91.59 & 0.65 & 91.59 \\
\hline 40 & 0.16 & 23.06 & 0.63 & 92.22 & 0.63 & 92.22 \\
\hline 41 & 0.15 & 23.21 & 0.62 & 92.84 & 0.62 & 92.84 \\
\hline 42 & 0.15 & 23.36 & 0.60 & 93.44 & 0.60 & 93.44 \\
\hline 43 & 0.15 & 23.51 & 0.59 & 94.03 & 0.59 & 94.03 \\
\hline 44 & 0.14 & 23.65 & 0.57 & 94.60 & 0.57 & 94.60 \\
\hline 45 & 0.14 & 23.79 & 0.56 & 95.17 & 0.56 & 95.17 \\
\hline 46 & 0.14 & 23.93 & 0.55 & 95.72 & 0.55 & 95.72 \\
\hline 47 & 0.13 & 24.06 & 0.54 & 96.25 & 0.54 & 96.25 \\
\hline
\end{tabular}

Table B2

Production table Type-II X

\begin{tabular}{|c|c|c|c|c|c|c|c|c|c|c|c|c|c|c|c|c|c|c|c|c|c|}
\hline \multirow[t]{2}{*}{ Units W } & \multicolumn{21}{|c|}{ Units V } \\
\hline & 0 & 1 & 2 & 3 & 4 & 5 & 6 & 7 & 8 & 9 & 10 & 11 & 12 & 13 & 14 & 15 & 16 & 17 & 18 & 19 & 20 \\
\hline 0 & 0 & 0 & 0 & 0 & 0 & 0 & 0 & 0 & 0 & 0 & 0 & 0 & 0 & 0 & 0 & 0 & 0 & 0 & 0 & 0 & . \\
\hline 1 & 0 & 2 & 3 & 3 & 3 & 3 & 3 & 3 & 3 & 3 & 3 & 3 & 3 & 3 & 3 & 3 & 3 & 3 & 3 & 3 & . \\
\hline 2 & 0 & 2 & 3 & 4 & 5 & 5 & 5 & 5 & 5 & 5 & 5 & 6 & 6 & 6 & 6 & 6 & 6 & 6 & 6 & 6 & . \\
\hline 3 & 0 & 2 & 4 & 5 & 6 & 6 & 7 & 7 & 7 & 7 & 8 & 8 & 8 & 8 & 8 & 8 & 8 & 8 & 8 & 8 & . \\
\hline 4 & 0 & 2 & 4 & 5 & 6 & 7 & 8 & 8 & 9 & 9 & 9 & 10 & 10 & 10 & 10 & 10 & 10 & 10 & 10 & 10 & . \\
\hline 5 & 0 & 2 & 4 & 5 & 7 & 8 & 9 & 9 & 10 & 10 & 11 & 11 & 11 & 11 & 12 & 12 & 12 & 12 & 12 & 12 & . \\
\hline 6 & 0 & 2 & 4 & 6 & 7 & 8 & 9 & 10 & 11 & 11 & 12 & 12 & 13 & 13 & 13 & 13 & 14 & 14 & 14 & 14 & . \\
\hline 7 & 0 & 2 & 4 & 6 & 7 & 8 & 10 & 11 & 11 & 12 & 13 & 13 & 14 & 14 & 15 & 15 & 15 & 15 & 16 & 16 & . \\
\hline 8 & 0 & 2 & 4 & 6 & 7 & 9 & 10 & 11 & 12 & 13 & 13 & 14 & 15 & 15 & 16 & 16 & 16 & 17 & 17 & 17 & . \\
\hline 9 & 0 & 2 & 4 & 6 & 7 & 9 & 10 & 11 & 12 & 13 & 14 & 15 & 15 & 16 & 17 & 17 & 17 & 18 & 18 & 19 & . \\
\hline 10 & 0 & 2 & 4 & 6 & 7 & 9 & 10 & 11 & 13 & 14 & 15 & 15 & 16 & 17 & 17 & 18 & 18 & 19 & 19 & 20 & . \\
\hline 11 & 0 & 2 & 4 & 6 & 7 & 9 & 10 & 12 & 13 & 14 & 15 & 16 & 17 & 17 & 18 & 19 & 19 & 20 & 20 & 21 & . \\
\hline 12 & 0 & 2 & 4 & 6 & 7 & 9 & 10 & 12 & 13 & 14 & 15 & 16 & 17 & 18 & 19 & 19 & 20 & 21 & 21 & 22 & . \\
\hline 13 & 0 & 2 & 4 & 6 & 7 & 9 & 10 & 12 & 13 & 14 & 15 & 17 & 17 & 18 & 19 & 20 & 21 & 21 & 22 & 23 & . \\
\hline 14 & 0 & 2 & 4 & 6 & 7 & 9 & 11 & 12 & 13 & 15 & 16 & 17 & 18 & 19 & 20 & 20 & 21 & 22 & 23 & 23 & . \\
\hline 15 & 0 & 2 & 4 & 6 & 7 & 9 & 11 & 12 & 13 & 15 & 16 & 17 & 18 & 19 & 20 & 21 & 22 & 23 & 23 & 24 & . \\
\hline 16 & 0 & 2 & 4 & 6 & 7 & 9 & 11 & 12 & 13 & 15 & 16 & 17 & 18 & 19 & 20 & 21 & 22 & 23 & 24 & 24 & . \\
\hline 17 & 0 & 2 & 4 & 6 & 7 & 9 & 11 & 12 & 14 & 15 & 16 & 17 & 19 & 20 & 21 & 22 & 23 & 23 & 24 & 25 & . \\
\hline 18 & 0 & 2 & 4 & 6 & 7 & 9 & 11 & 12 & 14 & 15 & 16 & 17 & 19 & 20 & 21 & 22 & 23 & 24 & 25 & 25 & . \\
\hline 19 & 0 & 2 & 4 & 6 & 8 & 9 & 11 & 12 & 14 & 15 & 16 & 18 & 19 & 20 & 21 & 22 & 23 & 24 & 25 & 26 & . \\
\hline 20 & . & . & . & . & . & . & . & . & . & & & . & & & & . & 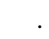 & & & . & . \\
\hline
\end{tabular}

\section{B.2. Production schedule of $X$-producer in home country of the international economy}

A production schedule for Type-II X (X-producer) is given in Table B2. 


\section{References}

Adam, K., 2005. Experimental evidence on the persistence of output and inflation. CEPR Discussion paper No. 4885. Akerlof, G.A., 2002. Behavioral macroeconomics and macroeconomic behaviour. American Economic Review 92, 411-433.

Aizenman, J., Marion, N.P., 1993. Macroeconomic uncertainty and private investment. Economics Letters 41, 207-210.

Anderson, P.M., Meyer, B.D., 2000. The effects of the unemployment insurance payroll tax on wages, employment, claims and denials. Journal of Public Economics 78, 81-106.

Ball, S., Eckel, C., Grossman, P.J., Zame, W., 2001. Status in markets. Quarterly Journal of Economics 116, $161-188$.

Batra, R.N., Ullah, A., 1974. Competitive firm and the theory of input demand under price uncertainty. Journal of Political Economy 82, 537-548.

Bosch-Domènech, A., Silvestre, J., 1997. Credit constraints in general equilibrium: Experimental results. The Economic Journal 107, 1445-1464.

Brockhaus Sr. R.H., 1982. The psychology of the entrepreneur. In: Kent, C.A., Sexton, D.L., Vesper, K.H. (Eds.), Encyclopaedia of Entrepreneurship. Prentice-Hall, Englewood Cliffs.

Brunetti, A., Weder, B., 1998. Investment and institutional uncertainty: A comparative study of different uncertainty measures. Weltwirtschaftliches Archiv 134, 513-533.

Daveri, F., Tabellini, G., 2000. Unemployment, growth and taxation in industrial countries. Economic Policy 15, 49-104.

Davis, D.D., Holt, Ch.A., 1993. Experimental Economics. Princeton University Press, Princeton.

Davis, J.S., Swenson, Ch.W., 1993. Experimental evidence on tax incentives and the demand for capital investments. The Accounting Review 68, 482-514.

Economic Policy: A European Forum, 1997. vol. 25.

Elmeskov, J., Martin, J.P., Scarpetta, S. (1998). Key lessons from labour market reforms: Evidence from OECD countries experiences, mimeo. Swedish Economic Policy Review 5, 205-252.

European Commission, 1994. Growth, competitiveness, employment: The challenges and ways forward into the 21st Century. White Paper, Office for Official Publications of the European Community, Luxembourg.

Ghosal, V., 1995. Input choices under price uncertainty. Economic-Inquiry 33, 142-158.

Goeree, J.K., Holt, Ch.A., 1999. Employment and prices in a simple macroeconomy. Southern Economic Journal 65, 637-647.

Gruber, J., 1997. The incidence of payroll taxation: Evidence from Chile. Journal of Labor Economics 15 , S72-S101.

Gunjal, K., Legault, B., 1995. Risk preferences of dairy and hog producers in Quebec. Canadian Journal of Agricultural-Economics 43, 23-35.

Hartman, R., 1975. Competitive firm and the theory of input demand under price uncertainty: Comment. Journal of Political Economy 83, 1289-1290.

Hartman, R., 1976. Factor demand with output price uncertainty. American Economic Review 66, 675-681.

Hey, J.D., di Cagno, D., 1998. Sequential markets: An experimental investigation of Clower's dual-decision hypothesis. Experimental Economics 1, 63-85.

Holthausen, D.M., 1976. Input choices and uncertain demand. American Economic Review 66, 94-103.

Kahneman, D., Tversky, A., 1979. Prospect theory: An analysis of decision under risk. Econometrica 47, 263-291.

Layard, R., Nickel, S., Jackman, R., 1991. Unemployment: Macroeconomic Performance and the Labour Market. Oxford University Press, Oxford.

Lian, P., Plott, Ch.R., 1998. General equilibrium, markets, macroeconomics and money in a laboratory experimental environment. Economic Theory 12, 21-75.

Myagkov, M., Plott, Ch.R., 1997. Exchange economies and loss exposure: Experiments exploring prospect theory and competitive equilibria in market environments. American Economic Review 87, 801-828.

Nickell, S., Layard, R., 1997. The labor market consequences of technical and structural change. Center for Economic Performance, Discussion Paper No. 23. Labor market institutions and economic performance, University of Oxford, Oxford.

Nickell, S., Layard, R., 1999. Labor market institutions and economic performance. In: Ashenfelder, O., Card, D. (Eds.), Handbook of Labor Economics. Elsevier, Amsterdam. 
Nickell, S., Nunziata, L., Ochel, W., 2005. Unemployment in the OECD since the 1960s. What do we know? The Economic Journal 115, 1-27.

Normann, H.-T., Riccuiti, R., 2004. Experiments for economic policy making. ENCORE opinion paper, University of Amsterdam.

Noussair, Ch.N., Plott, Ch.R., Riezman, R.G., 1995. An experimental investigation of the patterns of international trade. American Economic Review 85, 462-491.

Noussair, Ch.N., Plott, Ch.R., Riezman, R.G., 1997. The principles of exchange rate determination in an international finance experiment. Journal of Political Economy 105, 822-861.

Noussair, Ch.N., Plott, Ch.R., Riezman, R.G., 2003. Production, Trade, and Exchange Rates in Large Experimental Economies, Emory University, mimeo.

OECD, 1999. Employment outlook, OECD, Paris.

Oswald, A.J., 1997. The missing piece of the unemployment puzzle. Inaugural lecture, University of Warwick.

Pissarides, C.A., 1998. The impact of employment tax cuts on unemployment and wages: The role of unemployment benefits and tax structure. European Economic Review 42, 155-183.

Plott, Ch.R., Gray, P., 1990. The multiple unit double auction. Journal of Economic Behavior and Organization $13,245-258$.

van Praag, B.M.S., Halberstadt, V., 1980. Towards an economic theory of non-employability a first approach. In: Roskamp, K.W. (Ed.), Public Choice and Public Finance. Edition Cujas, Paris, pp. 211-222.

Quirmbach, H.C., Swenson, Ch.W., Vines, C.C., 1996. An experimental examination of general equilibrium tax incidence. Journal of Public Economics 61, 337-358.

Rochetau, G., 1999. Can an unemployment insurance system generate multiple natural rates? International Tax and Public Finance 6, 379-387.

Rogerson, R., 1997. Theory ahead of language in the economics of unemployment. Journal of Economic Perspectives 11, 73-92.

Roth, A.E., 2002. The economist as engineer: Game theory, experimentation, and computation as tools for design economics. Econometrica 70, 1341-1378.

Saltari, E., Ticchi, D., 2005. Risk-aversion and the investment-uncertainty relationship: A comment. Journal of Economic Behavior and Organization 56, 121-125.

Schram, A., 2005. Artificiality: The tension between internal and external validity in economic experiments. Journal of Economic Methodology 12, 225-237.

Snower, D.J., 1994. Converting unemployment benefits into employment subsidies. American Economic Review 84, 65-70.

Snower, D.J., 2000. Evolution of the welfare state. Schriften des Vereins für Socialpolitik 271, 35-52.

Sørenson, P.B., 1997. Public finance solutions to the European unemployment problem? Economic Policy: A European Forum 25, 221-251.

Stiglitz, J.E., 1999. Taxation, public policy, and dynamics of unemployment. International Tax and Public Finance 6, 239-262.

Tullio, G., 1987. Long run implications of the increase in taxation and public debt for employment and economic growth in Europe. European Economic Review 31, 741-780.

van Winden, F.A.A.M., Riedl, A., Wit, J. and van Dijk, F., 1999. Experimenteel onderzoek naar het plan van Elswijk: Eindrapport voor het Ministerie van Sociale Zaken en Werkgelegenheid. CREED, Universiteit van Amsterdam, Amsterdam.

Zhang, G., 1998. Ownership concentration risk aversion and the effect of financial structure on investment decisions. European Economic Review 42, 1751-1778. 